\title{
Speciation Analysis of Trace Arsenic, Mercury, Selenium and Antimony in Environmental and Biological Samples Based on Hyphenated Techniques
}

\author{
Xiaoping Yu *, Chenglong Liu, Yafei Guo® and Tianlong Deng * \\ Tianjin Key Laboratory of Marine Resources and Chemistry, College of Chemical Engineering and Materials \\ Science, Tianjin University of Science \& Technology, Tianjin 300457, China; 17302297916@163.com (C.L.); \\ guoyafei@tust.edu.cn (Y.G.) \\ * Correspondence: yuxiaoping@tust.edu.cn (X.Y.); tldeng@tust.edu.cn (T.D.); Tel.: +86-022-60601156 (X.Y.) \\ Academic Editors: Francesco Crea and Alberto Pettignano \\ Received: 1 February 2019; Accepted: 28 February 2019; Published: 7 March 2019

\begin{abstract}
In order to obtain a well understanding of the toxicity and ecological effects of trace elements in the environment, it is necessary to determine not only the total amount, but also their existing species. Speciation analysis has become increasingly important in making risk assessments of toxic elements since the toxicity and bioavailability strongly depend on their chemical forms. Effective separation of different species in combination with highly sensitive detectors to quantify these particular species is indispensable to meet this requirement. In this paper, we present the recent progresses on the speciation analysis of trace arsenic, mercury, selenium and antimony in environmental and biological samples with an emphasis on the separation and detection techniques, especially the recent applications of high performance liquid chromatography (HPLC) hyphenated to atomic spectrometry or mass spectrometry.
\end{abstract}

Keywords: arsenic; mercury; selenium; antimony; speciation analysis; hyphenated technique

\section{Introduction}

Trace elements, as important components of the environment, play crucial roles in the functioning of life. Some elements such as arsenic (As), mercury ( $\mathrm{Hg}$ ) and antimony $(\mathrm{Sb})$ can be highly toxic to various life forms, while some others are probably considered to be essential, but they can become toxic at higher doses. For example, selenium (Se) is widely recognized as an essential dietary component with numerous beneficial effects on health, but at levels higher than $5 \mu \mathrm{g} / \mathrm{L}$ will cause toxic effects $[1,2]$. It is generally recognized that the mobility, toxicity and bioavailability of trace elements depend strongly on their particular existing forms, and the determination of species rather than the total amount of an element is more important [3]. Usually, the ecological and healthy risk assessments of trace elements in the environment based on the species data will seem to be more reasonable and accurate than the total amount data.

"Chemical species" refers to the specific form of an element defined as to isotopic composition, electronic or oxidation state, and/or complex or molecular structure [4]. Usually, compounds that differ in isotopic composition, conformation, oxidation or electronic state, or in the nature of their complexed or covalently bound substituents, can be regarded as distinct chemical species [5]. The division suggested by Tessier et al. [6] is usually recommended in the research relevant to the species of heavy metals in soil or sediment. They distinguished and defined five fractions, i.e., exchangeable, carbonate-bound, iron and manganese oxides-bound, organic matter-bound, and the other mineral-bound metals. In addition, the BCR or modified BCR sequential extraction method $[7,8]$ and the modified Tessier method [9] are also used to study the bound species of heavy metals in soil or 
sediment [10]. Nonetheless, these methods do not allow the differentiation between oxidation states of elements in aqueous phase, of which may be of great importance when considering their toxicity. $\mathrm{As}, \mathrm{Hg}$, Sb and Se probably exist in many forms in environmental and biological samples as shown in Table 1.

However, the main species existing in aquatic environments are inorganic forms, i.e., As(III), $\mathrm{As}(\mathrm{V}) ; \mathrm{Hg}(\mathrm{II}) ; \mathrm{Sb}(\mathrm{III}), \mathrm{Sb}(\mathrm{V})$; and $\mathrm{Se}(\mathrm{IV}), \mathrm{Se}(\mathrm{VI})$ [11-13], but methylation may occur in sediment environments due to the actions of microorganisms [14,15]. Selenosugars have been confirmed to be important urinary selenium metabolites, while selenohomolanthionine (SeHLan) is mainly detected in some Se-accumulating plants and yeasts [16-18]. Lipid-soluble arsenic compounds (arsenolipids) are mainly found in fish oils, fish liver, sashimi tuna, algae, et al. [19-21]. Of course, some unusual chemical species in biosamples or other complex samples probably exist. For example, tetramethylarsonium ion (TETRA), glyceryl phosphorylarsenocholine (GPAsC), and dimethylarsinothioic acid (DMAS) were found and identified in marine foods [22]; 4-aminophenylarsonic acid (4-APAA) and N-acetyl-4-hydroxyphenylarsonic acid (N-AHPAA) were found in chicken liver [23].

Table 1. Main species of As, $\mathrm{Hg}$, Se and Sb commonly detected in environmental and biological samples.

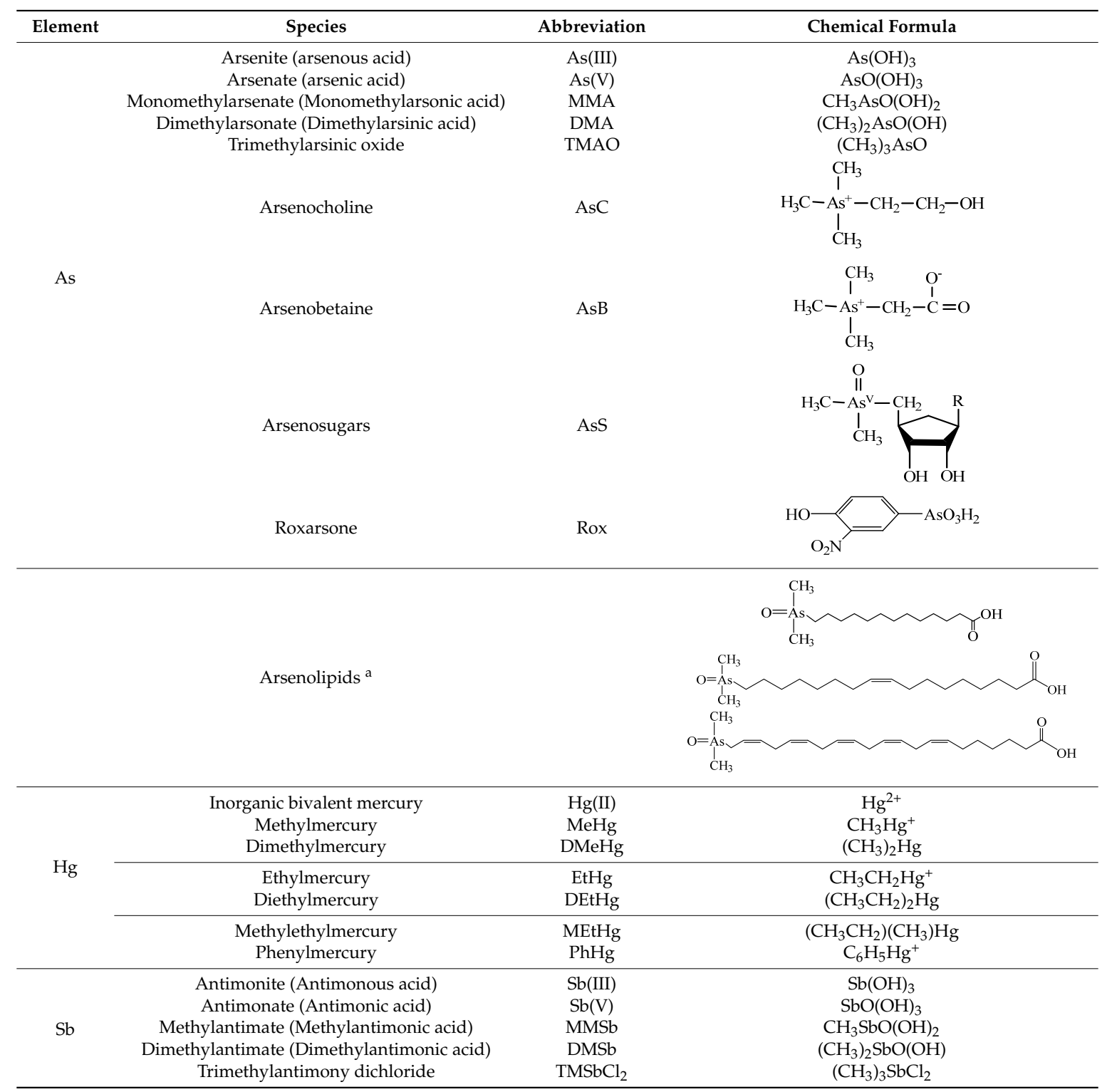


Table 1. Cont.

\begin{tabular}{|c|c|c|c|}
\hline Element & Species & Abbreviation & Chemical Formula \\
\hline \multirow{13}{*}{ Se } & Selenite & $\mathrm{Se}(\mathrm{IV})$ & $\mathrm{H}_{2} \mathrm{SeO}_{3}$ \\
\hline & Selenate & $\mathrm{Se}(\mathrm{VI})$ & $\mathrm{H}_{2} \mathrm{SeO}_{4}$ \\
\hline & Selenomethionine & SeMet & $\mathrm{CH}_{3} \mathrm{SeCH}_{2} \mathrm{CH}_{2} \mathrm{CH}\left(\mathrm{NH}_{2}\right) \mathrm{COOH}$ \\
\hline & Selenocysteine & SeCys & $\mathrm{HSeCH}_{2} \mathrm{CH}\left(\mathrm{NH}_{2}\right) \mathrm{COOH}$ \\
\hline & Se-methylselenocysteine & SeMeCys & $\mathrm{CH}_{3} \mathrm{SeCH}_{2} \mathrm{CH}\left(\mathrm{NH}_{2}\right) \mathrm{COOH}$ \\
\hline & Selenoethionine & SeEt & $\mathrm{CH}_{3} \mathrm{CH}_{2} \mathrm{SeCH}_{2} \mathrm{CH}_{2} \mathrm{CH}\left(\mathrm{NH}_{2}\right) \mathrm{COOH}$ \\
\hline & Selenocystine & $\mathrm{SeCys}_{2}$ & $\mathrm{HOOCCH}\left(\mathrm{NH}_{2}\right) \mathrm{CH}_{2} \mathrm{Se}_{-} \mathrm{SeCH}_{2} \mathrm{CH}\left(\mathrm{NH}_{2}\right) \mathrm{COOH}$ \\
\hline & Selenohomolanthionine & SeHLan & $\mathrm{HOOCCH}\left(\mathrm{NH}_{2}\right) \mathrm{CH}_{2} \mathrm{CH}_{2} \mathrm{SeCH}_{2} \mathrm{CH}_{2} \mathrm{CH}\left(\mathrm{NH}_{2}\right) \mathrm{COOH}$ \\
\hline & Trimethylselenonium ion & $\mathrm{TMSe}^{+}$ & $\left(\mathrm{CH}_{3}\right)_{3} \mathrm{Se}^{+}$ \\
\hline & Selenocyanate & $\mathrm{SeCN}^{-}$ & $\mathrm{N} \equiv \mathrm{C}-\mathrm{Se}^{-}$ \\
\hline & Selenosugar 1 & SeSug 1 & \\
\hline & Selenosugar 2 & SeSug 2 & \\
\hline & Selenosugar 3 & SeSug 3 & \\
\hline
\end{tabular}

a Some identified arsenic-containing fatty acids in cod-liver oil [21].

The lack of accurate speciation information is the major limitation for us to understand the environmental biogeochemical cycles of trace elements in the aquatic environments. In view of this, speciation analysis has become one of the fastest developed areas of analytical chemistry over the last two decades. "Speciation analysis" is defined by the IUPAC as analytical activities of identifying and/or measuring the quantities of one or more individual chemical species in a sample. It plays a unique role in the studies of biogeochemical cycles of compounds, determination of toxicity and eco-toxicity of selected elements, quality control of food products, control of medicines and pharmaceutical products, examination of occupational exposure and clinical analysis, etc. [24]. Generally, two complementary techniques are necessary for the speciation analysis of trace elements, i.e., separation and detection. The former provides an efficient and reliable separation of the species, and the latter provides adequate detection and quantification. Progresses in analytical instruments and methodology allow us to identify and measure the species presented in a particular system. Especially, the coupling of chromatographic techniques, such as gas chromatography (GC) and high performance liquid chromatography (HPLC), with a highly sensitive and selective detector, such as mass spectrometry (MS) or atomic spectrometry including atomic fluorescence spectrometry (AFS), atomic absorption spectrometry (AAS), and atomic emission spectrometry (AES) or optical emission spectrometry (OES) has been widely exploited and accepted for the speciation analysis of trace elements. Even though several reviews have been dedicated to the speciation analysis of $\mathrm{As}, \mathrm{Hg}$, $\mathrm{Se}$, and $\mathrm{Sb}$ [25-32], this presented work reviews and discusses the different separation and detection methods for the speciation analysis of trace $\mathrm{As}, \mathrm{Hg}$, Se and $\mathrm{Sb}$ in environmental and biological samples with an emphasis on the hyphenated techniques.

\section{Separation Techniques for Speciation Analysis}

\subsection{Non-Chromatographic Methods}

The chemical form and quantitative information of a given element can be acquired by the application of basic chemistry methods. In other word, non-chromatographic procedures can provide simple methods to obtain sufficient information on the elemental species. Many review papers are 
available for the non-chromatographic speciation analysis methods [33-35], and the commonly used for $\mathrm{As}, \mathrm{Hg}$, Se and $\mathrm{Sb}$ include extraction and selective reduction.

\subsubsection{Extraction}

Extraction is usually used to separate one or a group of species from complex matrices, especially for environmental and biological samples [36,37]. Liquid-liquid extraction (LLE) is the oldest pre-concentration and isolation method for speciation analysis, and can be directly applied for the non-filtered samples with complex matrices [38]. Sequential extraction procedures using aqueous solutions, such as the Tessier or BCR method, are usually used to characterize the mobility, bioavailability, and potential toxicity of trace elements in soil and sediment. LLE may perform best for the redox labile elements such as $\mathrm{As}, \mathrm{Sb}$ and $\mathrm{Se}$, for which more discrete biogeochemical species may be generated due to the variations in oxidation number. At present, LLE is rarely applied for elemental species in water samples except for the extraction of different bounded species in sediment or soil. Some modified LLE methods are also used for speciation analysis. For example, ultrasonic assisted dispersive liquid-liquid microextraction (LLME) was used by Panhwar et al. [39] to analyze Se(IV) and Se(VI) in water and food samples. A vortex assisted dispersive liquid-liquid microextraction method based on the freezing of deep eutectic solvent was developed by Akramipour et al. [40] for the determination of organic and inorganic mercury in blood samples. Based on the principles of extraction, some other extracting methods have been developed including liquid phase microextraction (LPME) [41,42], solid phase extraction (SPE) [43,44], solid phase microextraction (SPME) [45-48], etc.

LPME is introduced to reduce the consumption of solvent, in which a drop of organic solvent is suspended at the tip of a microsyringe and exposed to the analytical sample. Subsequently, the drop is retracted and transferred to a particular analytical instrument after extraction. For example, speciation analysis of As(III) and As(V) based on Triton X-100 hollow fiber LPME coupled with flame atomic absorption spectrometry (FAAS) was developed by Zeng et al. [42], during which the Triton $\mathrm{X}-100$ was used as an extractant and an acceptor solution; Fan [49] determined $\mathrm{Sb}(\mathrm{III})$ and total $\mathrm{Sb}$ in natural water by electrothermal atomic absorption spectrometry (ET-AAS) prior to separate and preconcentrate using $N$-benzoyl- $N$-phenylhydroxylamine-chloroform single drop; Single-drop gold nanoparticles for headspace microextraction and colorimetric assay of $\mathrm{Hg}$ (II) in environmental waters was developed by Tolessa et al. [50], and the recovery for a $10 \mathrm{nM}$ spiked level was in the range of $86.8 \sim 99.8 \%$.

SPE is popular for sample preparation in organic analysis, but it is also found to be used for speciation analysis of inorganic elements. The analytes are extracted by selective sorption and subsequently derivatized or directly detected after eluted with a small amount of organic solvent $[51,52]$. Sorbents with an immobilized chelating reagent such as ammonium pyrrolidine dithiocarbamate (APDC) are widely used in SPE. For example, a new magnetic SPE using octyl-immobilized silica-coated magnetic $\mathrm{Fe}_{3} \mathrm{O}_{4}\left(\mathrm{C}_{8}-\mathrm{Fe}_{3} \mathrm{O}_{4} @ \mathrm{SiO}_{2}\right)$ nanoparticles was proposed by $\mathrm{Li}$ et al. [53] for the determination of trace $\mathrm{Sb}(\mathrm{III})$ and $\mathrm{Sb}(\mathrm{V})$ in water, during which $\mathrm{Sb}(\mathrm{III})$ forms a hydrophobic complex with APDC at pH 5.0 and is retained on $\mathrm{C}_{8}-\mathrm{Fe}_{3} \mathrm{O}_{4} @ \mathrm{SiO}_{2}$ nanoparticles, whereas $\mathrm{Sb}(\mathrm{V})$ remains as free species in aqueous solution. A method for multi-element inorganic speciation analysis of $\mathrm{As}(\mathrm{III}, \mathrm{V}), \mathrm{Se}(\mathrm{IV}, \mathrm{VI})$ and $\mathrm{Sb}(\mathrm{III}, \mathrm{V})$ in natural water using SPE technology was developed by Zhang et al. [54], during which $\mathrm{TiO}_{2}$ was used to adsorb total inorganic As, Se and Sb, while As(III), $\mathrm{Se}(\mathrm{IV})$ and $\mathrm{Sb}(\mathrm{III})$ were coprecipitated with $\mathrm{Pb}-\mathrm{PDC}$. The concentration of $\mathrm{As}(\mathrm{V}), \mathrm{Se}(\mathrm{VI})$ and $\mathrm{Sb}(\mathrm{V})$ was subsequently calculated by the differences. Recently, Peng et al. [55] synthesized and employed functionalized multi-wall carbon nanotubes as the adsorbent for simultaneous speciation analysis of inorganic As, Se and chromium $(\mathrm{Cr})$ in environmental waters by microcolumn SPE. The detection limits of 15,38 and $16 \mathrm{ng} / \mathrm{L}$ were obtained for $\mathrm{As}(\mathrm{V}), \mathrm{Cr}(\mathrm{VI})$ and $\mathrm{Se}(\mathrm{VI})$, respectively.

SPME offers a fast way for species separation by collecting target analytes from the sample headspace or liquid phase directly or after derivatization. It offers the possibility to eliminate the interferences from matrices without the use of organic solvents [44,56,57]. For example, headspace 
SPME coupled to miniaturized microplasma OES was developed by Zheng et al. [57] for the detection of mercury and lead in water samples. It is noted that SPME is also often used as a pretreatment method to separate or preconcentrate analytes prior to chromatographic separation [58,59]. Of course, direct coupling of SPME with particular detectors is also developed. For example, SPME was used by Panhwar et al. [45] for the determination of inorganic Sb speciation. $\mathrm{Sb}$ (III) forms hydrophobic complex with diethyl dithiocarbamate at pH 5.5 and subsequently adsorbed on polystyrene oleic acid imidazole polymer. A screening method was developed by Mester [60] to determine volatile metallic compounds (As, Se, Sn and Sb) in solid samples by examining the vapor phase above the sample with a SPME probe. The total analysis time was less than three minutes depending on the concentration of the target compounds.

Some assistant extracting techniques such as microwave-assisted extraction (MWAE) and ultrasound-assisted extraction (USAE) [39,61-64] have also been applied for speciation analysis so as to improve the speed of extraction. It is noted that although extraction methods can realize the determination of elemental speciation, they are usually used as pretreatment procedures for elemental speciation in complex samples followed by the chromatographic hyphenated techniques for species separation and detection [65-67]. For example, in order to determine As speciation in guano and ornithogenic sediments, MWAE was used by Lou et al. [65] to extract As(III), DMA, MMA, and As(V) in these sediments followed by the detection of HPLC-HG-AFS.

\subsubsection{Selective Reduction}

Selective reduction is used based on the differences of reduction potential between different species. The reduction potential can be controlled by the concentration of reductants, $\mathrm{pH}$, as well as by the presence of catalysts or chelating agents. Selective reduction is generally related to the chemical vapor generation (CVG) methods, by which the volatile derivatives are produced during reduction $[68,69]$.

It is noted that some organic Se and $\mathrm{Hg}$ species are not easily reduced by $\mathrm{BH}_{4}{ }^{-}$, which is the most frequently used reductant during CVG. In view of this, photochemical reduction by exposure to ultraviolet (UV) irradiation or ultrasound (US) is often used. For example, when $\mathrm{Hg}$ (II) and $\mathrm{MeHg}$ were determined by $\mathrm{Hu}$ et al. [70] using hydride generation ultraviolet atomization-AFS, the $\mathrm{Hg}$ (II) can be directly measured under the non-ultraviolet radiation mode after reducing using $0.1 \%(\mathrm{~m} / \mathrm{v})$ $\mathrm{KBH}_{4}$, while the MeHg needs to be transformed into elemental mercury vapor under the ultraviolet atomization. when total $\mathrm{Hg}$ and $\mathrm{MeHg}$ in biological samples were detected by Vieira et al. [71], total $\mathrm{Hg}$ was measured after the tissues were digested in either formic acid or tetramethylammonium hydroxide (TMAH) following the reduction of both species by exposure the solution to UV irradiation, during which $\mathrm{MeHg}$ was selectively quantitated by adding of $10 \% v / v$ acetic acid into TMAH solution. Mendez et al. [72] assessed the UV and US induced redox reactions for the determination of Se(IV), $\mathrm{Se}(\mathrm{VI})$, SeMet, and SeCys in model water, enriched natural water, and soil/fly ash extracts using HG-AAS and AFS. Furthermore, Chen et al. [73] systematically studied the photochemical behaviors of selenium and some of its organic compounds in various aqueous matrices under UV irradiation at $300 \mathrm{~nm}$. It was observed that the photochemical oxidation rate of Se(IV) to Se(VI) was greatly enhanced in the presence of $\mathrm{HNO}_{3}$ at concentration larger than $1 \times 10^{-3} \mathrm{M}$. Subsequently, the same authors [74] developed a method for the speciation analysis of Se in natural waters based on the photochemical reactions of Se(IV) and organic selenium in different aqueous solutions.

\subsubsection{Miscellaneous Methods}

Due to the different volatility of $\mathrm{Hg}$ and its compounds, thermal desorption is also used to distinguish their different species. For example, thermal release analysis in combination with AAS was developed and applied by Shuvaeva et al. [75] to determine $\mathrm{Hg}(\mathrm{II}), \mathrm{MeHg}$, and mercury sulfide in lake sediment and plankton. Similar technique was also used by Kaercher et al. [76] for the determination of inorganic and total $\mathrm{Hg}$ in biological samples based on the temperature control of the measurement 
cell. Masking with relevant masking agents is sometimes used for speciation analysis. For example, 8-hydroxyquinoline was used as an effective masking agent by Liao and Deng [77] for As speciation analysis in porewater and sediment. In addition, in order to realize redox speciation analysis of Sb in water, $\mathrm{Xi}$ et al. [78] systematically tested several compounds as masking agents to inhibit the generation of stibine from $\mathrm{Sb}(\mathrm{V})$, and the results indicated that citric acid and $\mathrm{NaF}$ can successfully suppress this process.

It is noted that any pretreatment processes during speciation analysis even the routine processes such as the changes of $\mathrm{pH}$, temperature and pressure can bring about irreversible transformation of the analyzed species. Non-chromatographic speciation analysis methods often employ multi-step procedures resulting in a high risk for the loss of analytes or species conversion. In this sense, these characteristics make such methods very difficult to automate and integrate into modern systems. Therefore, high selective and sensitive analytical methods without or with few pretreatment steps are more competent for speciation analysis.

\subsection{Chromatographic Hyphenated Techniques}

The most detailed information in relation to speciation analysis is no doubt derived from hyphenated techniques, in particular those involving separation by HPLC, GC or CE with ICP-MS or atomic spectrometry detectors. The main advantages of those techniques include extremely low detection limit, insignificant interference, high precision and repeatability, etc. The selection of a proper separation technique depends on the physico-chemical properties such as volatility, charge or polarity of the different species, and sometimes combination of two or more separation methods is also adopted.

\subsubsection{Gas Chromatography}

GC is mainly used for Hg species separation when compared with that used for As, Se and $\mathrm{Sb}$, during which volatile $\mathrm{Hg}$ species are stripped from the sample solution after derivatization, and subsequently pre-concentrated mainly through sorptive, extraction, etc [79-81]. The trapped Hg derivatives are then released thermally and transferred quantitatively to the GC for species separation.

Because the packed columns will lead to poor reproducibility, thus capillary or multi-capillary GC is usually used to provide superior separation power and better detection limits [82]. Usually, the $\mathrm{Hg}$ derivatives need to be quantitatively transferred to a suitable detection system after the GC separation. A comparative study of GC coupled with AFS, AES and MS for MeHg and EtHg analysis following aqueous derivatization was conducted by Cai et al. [83], and found that both GC-AFS and GC-AES shown to be excellent techniques with detection limits in the range of sub-picogram levels. Nevado et al. [84] also evaluated the advantages and disadvantages of three hyphenated techniques including GC-MS, GC-ICP-MS and GC-pyrolysis-AFS for Hg speciation analysis in different sample matrices after aqueous ethylation with sodium tetraethylborate. Absolute detection and quantification limits were in the range of $1 \sim 4$ pg for GC-MS, 0.05 0.21 pg for GC-ICP-MS, and 2 6 pg for GC-pyro-AFS.

Of course, there are also some applications of GC on the speciation analysis of As, Se and $\mathrm{Sb}$ [85-89]. For example, volatile organic Se compounds of dimethylselenide (DMSe) and dimethyldiselenide (DMDSe) in environmental and biological samples were determined by Ghasemi et al. [88] using a headspace hollow fiber protected LPME combined with capillary GC-MS. It is noted that although GC attracts particular attention due to its high efficiency and simplicity of coupling, however, in contrast to GC, HPLC has the ability of dealing with non-volatile compounds without any derivatization in some cases, and thus extending the range of application.

\subsubsection{Liquid Chromatography}

Among the most popular hyphenated techniques used for the determination of $\mathrm{As}, \mathrm{Hg}$, Se and $\mathrm{Sb}$ species, the coupling of various liquid chromatographies (LC) including ion-exchange chromatography 
(IEC) and reverse-phase chromatography (RPC) with particular detectors has obtained the fastest development [90]. Table 2 shows the recent applications of hyphenated techniques based on LC separation for the speciation analysis of $\mathrm{As}, \mathrm{Hg}$, $\mathrm{Sb}$ and $\mathrm{Se}$ in environmental and biological samples.

Table 2. Some publications of hyphenated techniques based on LC for the speciation analysis of As, $\mathrm{Hg}$, $\mathrm{Sb}$ and Se in environmental and biological samples in recent three years.

\begin{tabular}{|c|c|c|c|c|c|}
\hline Element & Species & Column & Detector & Matrix & Ref. \\
\hline \multirow{13}{*}{ As } & As(III), As(V), DMA, MMA & Hamilton PRP-X100 & ICP-MS & Rice & [91] \\
\hline & As(III), As(V), DMA, MMA & Agilent ZORBAX SB-Aq & ICP-MS & Cynomolgus macaques & [92] \\
\hline & $\mathrm{As}(\mathrm{III}), \mathrm{As}(\mathrm{V}), \mathrm{DMA}, \mathrm{MMA}, \mathrm{AsB}, \mathrm{AsC}$ & Dionex IonPac AS19 & ICP-MS & Ophiocordyceps sinensis & [93] \\
\hline & $\mathrm{As}(\mathrm{III}), \mathrm{As}(\mathrm{V})$ & Hamilton PRP-X100 & ICP-MS & Spring, well, and tap water & [95] \\
\hline & $\mathrm{As}(\mathrm{III}), \mathrm{As}(\mathrm{V}), \mathrm{DMA}, \mathrm{MMA}, \mathrm{AsB}, \mathrm{AsC}$ & Dionex IonPac AS7 & ICP-MS & Bones $\mathrm{r}$ & [96] \\
\hline & $\mathrm{As}(\mathrm{III}), \mathrm{As}(\mathrm{V}), \mathrm{DMA}, \mathrm{MMA}, \mathrm{AsB}, \mathrm{AsC}$ & Dionex IonPac AS7 & ICP-MS & Fish & [97] \\
\hline & $\mathrm{As}(\mathrm{III}), \mathrm{As}(\mathrm{V})$ & Hamilton PRP-X100 & ICP-MS & Mexican maize tortillas & [100] \\
\hline & $\mathrm{As}(\mathrm{III}), \mathrm{As}(\mathrm{V}), \mathrm{DMA}, \mathrm{MMA}, \mathrm{AsB}, \mathrm{AsC}$ & Dionex IonPac AS19 & ICP-MS & Edible Mushrooms & [101] \\
\hline & $\mathrm{As}(\mathrm{III}), \mathrm{As}(\mathrm{V}), \mathrm{DMA}, \mathrm{MMA}, \mathrm{AsB}$ & Hamilton PRP-X100 & HG-AFS & Seafood & [102] \\
\hline & As(III), As(V), DMA, MMA, AsB & Hamilton PRP-X10 & ICP-MS/MS & Seafood & [103] \\
\hline & $\mathrm{As}(\mathrm{III}), \mathrm{As}(\mathrm{V}), \mathrm{AsB}$ & Dionex IonPac AS9-HC & ICP-MS & Water and biota samples & [104] \\
\hline & $\mathrm{As}(\mathrm{III}), \mathrm{As}(\mathrm{V})$ & Hamilton PRP-X100 & ICP-MS & Natural water & [105] \\
\hline & DMA, AsB & Spheris S5SCX & ICP-MS & Fish & [106] \\
\hline \multirow{8}{*}{$\mathrm{Hg}$} & $\mathrm{Hg}(\mathrm{II}), \mathrm{MeHg}, \mathrm{EtHg}$ & ZORBAX SB-C18 & ICP-MS & Sea Cucumber & [109] \\
\hline & $\mathrm{Hg}(\mathrm{II}), \mathrm{MeHg}, \mathrm{EtHg}$ & Venusil MP-C18 & CV-AFS & Natural water & [110] \\
\hline & $\mathrm{Hg}(\mathrm{II}), \mathrm{MeHg}, \mathrm{EtHg}$ & PerkinElmer C8 & ICP-MS & Fish oils & [111] \\
\hline & $\mathrm{Hg}(\mathrm{II}), \mathrm{MeHg}, \mathrm{PhHg}$ & Hypersil ODS2 C18 & ICP-MS & Water and fish samples & [112] \\
\hline & $\mathrm{Hg}(\mathrm{II}), \mathrm{MeHg}$ & CLC-ODS C18 & ICP-MS & Water & [113] \\
\hline & $\mathrm{Hg}(\mathrm{II}), \mathrm{MeHg}$ & CLC-ODS C18 & ICP-MS & Water & {$[114]$} \\
\hline & $\mathrm{Hg}(\mathrm{II}), \mathrm{MeHg}, \mathrm{EtHg}$ & Agilent Eclipse plus C18 & ICP-MS & Rice & {$[115]$} \\
\hline & $\mathrm{Hg}(\mathrm{II}), \mathrm{MeHg}, \mathrm{EtHg}$ & Synergi Hydro-RP C18 & ICP-MS & Polluted sediments & [116] \\
\hline \multirow{3}{*}{ Se } & Se(IV), Se(VI), SeMet, SeCys & Spheris S5 SAX & ICP-MS & Chicken breast & [117] \\
\hline & Se(IV), Se(VI), SeMet, SeCys & Hamilton PRP-X100 & HG-AFS & Cordyceps militaris & [118] \\
\hline & $\begin{array}{c}\text { Se(IV), Se(VI), SeMet, SeCys, } \\
\text { SeMeCys }\end{array}$ & StableBond C18 & ICP-MS & Rice & [119] \\
\hline
\end{tabular}

The separation of species in IEC is based on the interactions between the positively or negatively charged species and the stationary phase that contains a cationic functional group (anion exchange) or an anionic functional group (cation exchange). IEC is an ideal technique for the separation of inorganic As, Sb, Se and many charged organometallic ions such as organoselenium and organoarsenic. Buffer solutions are commonly used as eluents for IEC with concentration usually not exceeding $25 \mathrm{mM}$. RPC is used based on the partition of the analytes between a non-polar stationary phase, in which it usually contains a covalently bound $\mathrm{C}_{8}$ or $\mathrm{C}_{18}$ linear hydrocarbon, and a relatively polar mobile phase. RPC is usually superior to IEC for the separation of organometallic species. Figure 1 shows the representative chromatograms of As [127], $\mathrm{Hg}$ [128], Se [129], and Sb [123] species in aqueous solutions separated by IEC or RPC. 


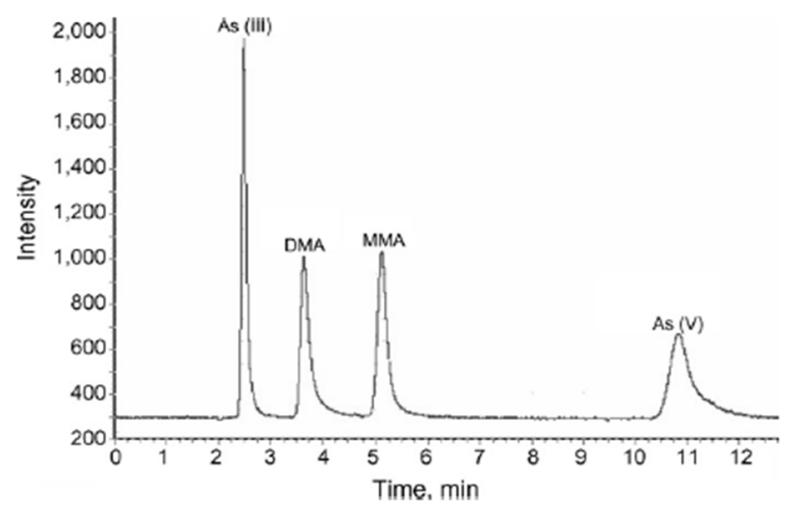

(a) As

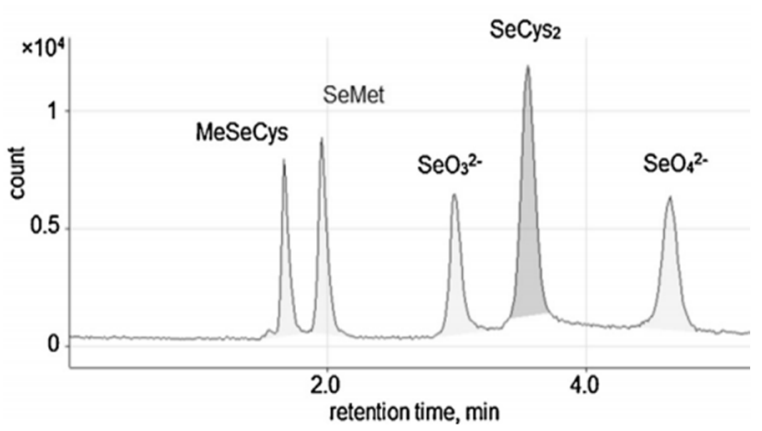

(c) Se

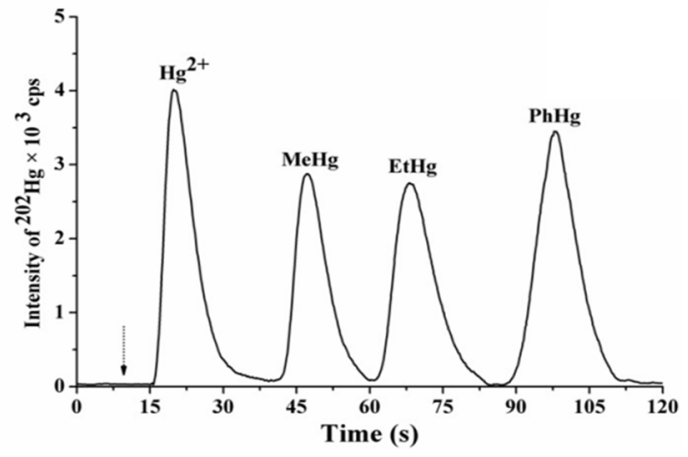

(b) $\mathrm{Hg}$

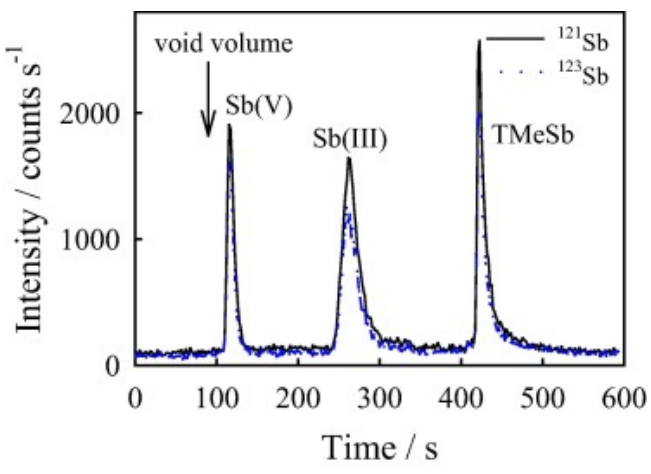

(d) $\mathrm{Sb}$

Figure 1. Representative chromatograms of As, $\mathrm{Hg}$, Se, and Sb species. (a) As: each at $100 \mu \mathrm{g} / \mathrm{L}$. Detected by HG-AFS after separated by a Hamilton PRP-X100 column $(250 \mathrm{~mm} \times 4.1 \mathrm{~mm}$ i.d., $10 \mu \mathrm{m})$ and eluted using $15 \mathrm{mM}\left(\mathrm{NH}_{4}\right)_{2} \mathrm{HPO}_{4}(\mathrm{pH} 6.0)$ at $1.0 \mathrm{~mL} / \mathrm{min}$ flow rate [127]; (b) Hg: each at $5.0 \mu \mathrm{g} / \mathrm{L}$. Detected by ICP-MS after separated by two consecutive Zorbax SCX columns $(12.5 \mathrm{~mm} \times 4.6 \mathrm{~mm}$ i.d., $5 \mu \mathrm{m}$ ) and eluted by $2.0 \mathrm{mM}$ thiourea ( $\mathrm{pH} 2.0$ ) at $1.5 \mathrm{~mL} / \mathrm{min}$ flow rate [128]; (c) Se: Detected by ICP-MS after separated by a Dinoex IonPac AS11 anion exchange column (4 mm i.d. $\times 250 \mathrm{~mm})$ and eluted using $10 \mathrm{mM} \mathrm{NaHCO}_{3}$ with $2 \%$ acetonitrile ( $\mathrm{pH} 11$ adjusted with $20 \% \mathrm{NH}_{3}$ ) at $0.6 \mathrm{~mL} / \mathrm{min}$ flow rate [129]; (d) Sb: $1 \mu \mathrm{g} / \mathrm{L} \mathrm{Sb}(\mathrm{V}), 2 \mu \mathrm{g} / \mathrm{L} \mathrm{Sb}(\mathrm{III})$ and TMeSb. Detected by ICP-MS after separated by a Hamilton PRP-X100 column $(250 \times 4.1 \mathrm{~mm}$ i.d., $10 \mu \mathrm{m})$ and eluted using A: $20 \mathrm{mM}$ EDTA + $2 \mathrm{mM} \mathrm{KHP}$ (pH 5.5), B: $20 \mathrm{mM}+2 \mathrm{mM} \mathrm{KHP}+40 \mathrm{mM}\left(\mathrm{NH}_{4}\right)_{2} \mathrm{CO}_{3}+1 \%(v / v) \mathrm{CH}_{3} \mathrm{OH}(\mathrm{pH} 9.0)$ at $1.2 \mathrm{~mL} / \mathrm{min}$ flow rate [123].

IEC is the most extensively used method for $\mathrm{As}, \mathrm{Sb}$ and Se speciation separation, followed closely by the use of ion-pair reversed-phase chromatography (IP-RPC). Many factors, such as the $\mathrm{pH}$, ionic strength, concentration and flow rate of mobile phase, the concentration and species of organic modifiers, will all influence the separation and retention of analytes in IEC and IP-RPC. For example, arsenic species are neutral, anionic or cationic depending on the $\mathrm{pH}$. As a result, their retention will strongly depend on the $\mathrm{pH}$ of mobile phase. Therefore, anion-exchange chromatography is often used to separate As(III), As(V), MMA and DMA, while cation-exchange chromatography is used to separate $\mathrm{AsB}, \mathrm{AsC}, \mathrm{TMAO}, \mathrm{Me}_{4} \mathrm{As}^{+}$for such compounds at cationic or neutral states cannot be retained by an anion-exchange mechanism. Of course, both anion and cation exchange columns are sometimes used in a complementary fashion [130]. Based on the requirement of $\mathrm{pH}$, phosphate [131], carbonate [132], nitrate [133], acetate [134] or miscellaneous [122,135] are commonly used as buffers. The anion-exchange mode with phosphate buffer elution is classically used for the separation of As(III), As(V), MMA and DMA. Sodium salt buffer leaves carbon residue upon the sampler and skimmer 
cones of ICP-MS resulting in the instability of plasma and the shift of retention time. Therefore, mobile phases based on ammonium salts are often used. For example, the use of $\mathrm{NH}_{4} \mathrm{NO}_{3}$ as mobile phase was shown to produce good signal stability on the ICP-MS with minimal salt deposit on the sample and skimmer cones [136].

When IP-RPC is used for species separation, a counterion is added to the mobile phase, and a secondary chemical equilibrium of the ion-pair is used to control the retention and selectivity $[115,119,137]$. The resolutions of species depend on the concentration and kind of ion-pair reagents, organic modifiers (e.g., methanol or acetonitrile), ionic strength, and $\mathrm{pH}$ of the mobile phase, etc [138]. The most used ion-pair reagent is tetrabutylammonium (TBA, including hydroxide, phosphate and bromide). Le et al. [139] investigated a series of ion pair reagents having different strength such as methanesulfonate, ethanesulfonate, propanesulfonate for the simultaneous analysis of Se and As species in a reversed phase C18 column, and found that all seven As species investigated were well separated within 16 min using hexanesulfonate as ion pair reagent. Choosing a suitable $\mathrm{pH}$ of eluent is also critical for species separation by IP-RPC. For example, As(III) is a neutral species, and will be eluted in the void volume at a low $\mathrm{pH}$ of mobile phase. But it becomes a negatively charged species when the $\mathrm{pH}$ of mobile phase is increased above its $\mathrm{pK}_{\mathrm{a}}$ value of 9.2. Chromatographic column also plays an important role in the separation of species. Usually, different chromatographic columns of the same separation mechanism have different separation effects. For example, Ammann [140] investigated two different polymeric anion-exchangers: a low capacity, weakly hydrophobic material (AS11, Dionex) and a more frequently used higher capacity, higher hydrophobicmaterial (AS7, Dionex), and found that AS11 provided better retention for MMA, AsB, As(III) than AS7, whereas DMA and $\mathrm{Cl}^{-}$were more retained on AG7. Gao et al. [119] compared the separation effects of five selenium species by two anion-exchange columns (Hamilton PRP X-100 and Dionex AS19) and three typical reversed C18 columns (Agilent Eclipse Plus C18, Waters Xselect HSS T3 and StableBond C18), and found that the StableBond C18 is more robust or has a better resolution.

When LC is employed for Hg species separation, a RP column is commonly used. However, the organic solvent concentration in the mobile phase must be as low as possible in order to reduce carbon deposit on the ICP-MS instrument interface. In order to overcome the drawback caused by organic solvent, vapor generation (VG) technique can be employed after the LC separation, by which only the volatile $\mathrm{Hg}$ species are introduced into the plasma. Of course, $\mathrm{Hg}(\mathrm{II}), \mathrm{MeHg}, \mathrm{EtHg}$ and $\mathrm{PhHg}$ can be separated in a cation-exchange chromatographic column due to they present in positively charged ions. For example, the four species were separated and determined by Chen et al. [128] by the coupling of cation-exchange chromatographic separation with ICP-MS detection.

Both isocratic and gradient ion-exchange chromatographic systems are used for species separation. Gradient separation generally has better resolution among different species, and is often used to reduce analytical time of strong retention species. However, gradient IP-RPC is not commonly adopted when ICP-MS is used as detector due to the signal drift is likely when substantially changing the organic content of the mobile phase. In addition, as the differences in structure and charge of different species, a single chromatographic mechanism is probably not sufficient for simultaneous study of organic and inorganic species. Combination of different chromatographic modes has therefore been applied by using columns in series or column-switching systems. For example, Milstein et al. [141] successfully separated and determined As(III), As(V), MMA, DMA, AsB, and AsC by connecting cation- and anion-exchange columns in series and eluting by $\left(\mathrm{NH}_{4}\right)_{2} \mathrm{CO}_{3}$ buffer. Of course, it is noted that the mobile phase used in multidimensional chromatography should be compatible with both chromatographic mechanisms.

\subsubsection{Capillary Electrophoresis}

Capillary electrophoresis (CE) is discussed as a complementary technique to GC and HPLC, and is a powerful tool in element speciation with high separation capability and environmentally friendly nature due to the use of aqueous buffer solutions with moderate $\mathrm{pH}$ and its extremely low reagent 
and sample consumption [142]. For example, ten As compounds including As(III), As(V), MMA, DMA, AsB, AsC, Rox, o-arsanilic acid, p-ureidophenylarsonic acid, and 4-nitrophenylarsonic acid were simultaneously determined by Liu et al. [143] by CE coupled with ICP-MS. Of course, for the analysis of elements in complex matrices, some pretreatment steps such as microextraction techniques are often necessary prior to CE separation [144-146].

Separation by CE is usually faster than that by LC, and therefore is potentially a rapid and highly efficient separation technique. However, some problems are presented when CE is coupled to ICP-OES or ICP-MS due to liquid flow incompatibility, i.e., the liquid flow is one order of magnitude lower in $\mathrm{CE}$ than in ICP sample introduction system. The detection limit is often insufficient resulting from the very small sample volumes used in CE, and therefore some interface techniques were developed. For example, a novel system for CE and ICP sample introduction that incorporates a dedicated Flow Focusing ${ }^{\circledR}$ based nebulizer as aerosol generation unit was presented by Kovachev et al. [147], and on-line coupling of CE with ICP-MS was developed by Liu et al. [148] using a sprayer with a novel direct-injection high-efficiency nebulizer (DIHEN) chamber as the interface. HG technique is also often integrated into CE hyphenated systems to provide a kind interface method. For example, a microfluidic chip-based capillary electrophoresis ( $\mu$ chip-CE) HG system was interfaced with a microwave induced plasma optical emission spectrometry (MIP-OES) by Matusiewicz and Ślachciński [149] to provide $\mathrm{As}(\mathrm{III})$ and $\mathrm{As}(\mathrm{V})$ species separation capabilities. Although CE provides an effective measure to fulfill species separation, there still exist major challenges that limit its practical acceptance. For example, no sufficient care on possible changes in speciation during electrophoresis, no appropriate treatment on method validation and system suitability aspects, etc [150].

It is noted that although there has been significant progress in speciation analysis based on the hyphenated chromatographic separation with atomic spectrometry or mass spectrometry detectors, and these hyphenated methods can provide the most complete information on the species distributions and even structures, they also have themselves disadvantages. A limitation related to the hyphenated techniques is the low sample volume introduced into the system which leads to the necessity of a very sensitive detector. It sometimes seems that non-chromatographic techniques are more suitable if sample volume is not a limitation, and thus less sensitive and less expensive detectors can be used due to the possibility of separation and pre-concentration the desired species. In addition, investment and operational costs associated with hyphenated techniques sometimes also play important roles to restrict the spread of speciation analysis as a usual task.

\section{Detection Techniques for Speciation Analysis}

The selection of detection techniques depends on the concentration level of the species presented in the sample and also the type of matrix and its composition. In terms of the detection approaches for speciation analysis, they must be selective and extremely sensitive since the species of interest usually accounts for only a small fraction of the total amount. The frequently used detection methods with high selectivity and sensitivity for $\mathrm{As}, \mathrm{Hg}$, Se and $\mathrm{Sb}$ species can be classified into atomic spectrometry and mass spectrometry methods.

\subsection{Atomic Spectrometry Methods}

Atomic spectrometry are subdivided into AFS, AAS, and AES (or OES), among which AFS is the most often used method, and represents a suitable alternative to the other atomic spectrometric and mass spectrometric techniques [151]. The direct coupling between HPLC and detectors will probably suffer from the interferences from the sample matrices. Therefore, when AFS is used for speciation analysis of $\mathrm{As}$, Se, $\mathrm{Sb}$ and $\mathrm{Hg}$, $\mathrm{HG}$ technique for $\mathrm{As}, \mathrm{Se}, \mathrm{Sb}$, and cold vapor (CV) generation for $\mathrm{Hg}$ are commonly used as online post-column derivatization method to separate the analytes from sample matrices [152]. The integration of $\mathrm{HG} / \mathrm{CV}$ based on the reaction of $\mathrm{BH}_{4}{ }^{-}$with the acidized sample prior to detector is proved to be an effective measure to reduce interferences and background signal from the sample matrices. The detection limits lower than $\mu \mathrm{g} / \mathrm{L}$ will be obtained using HPLC-HG-AFS 
for As speciation analysis [153]. However, it is noted that transition metals presented in samples will cause serious interferences in HG process. Some improving measures such as mask may be taken into consideration $[77,78]$.

Although there are some reports about the applications of AFS for the speciation analysis of As, $\mathrm{Hg}$, Se, and Sb in recent years [70,108,154-158], the development of atomic spectrometry methods has not been as fast as one would like because they usually need to be used together with HG or $\mathrm{CV}$ technique, during which the post-column treatment generally is required by the nature of this technique. In other word, HG is most suitable for low valence hydride-forming species, i.e., As(III), $\mathrm{Sb}$ (III), $\mathrm{Hg}$ (II) and Se(IV). However, the other inorganic or organic species can not or only present low reaction efficiency. In order to fulfill on-line and simultaneously speciation analysis, some pretreatment measures need to be adopted. For example, in order to simultaneously separate and determine organic species, on-line thermal microwave or UV irradiation prior to HG in the presence of strong oxidizing agents is developed to decompose the organic species. The latter is the most often used and inexpensive method for no cooling system is required after decomposition. For example, de Quadros et al. [159] developed a procedure for simultaneous determination of $\mathrm{Hg}(\mathrm{II}), \mathrm{MeHg}, \mathrm{EtHg}$ by photodecomposition of organomercury compounds and reduction of $\mathrm{Hg}$ (II) to mercury vapor under microwave/ultraviolet (MW/UV) irradiation. Of course, some other new methods such as post-column oxidation using $\mathrm{Fe}_{3} \mathrm{O}_{4}$ magnetic nanoparticles [160] were also developed to on-line convert hydride generation/cold vapor generation inactive species into their active species. For example, Sun et al. [161] developed an on-line digestion device based on the nano- $\mathrm{TiO}_{2}$-catalyzed photo-oxidation of As species. Illuminating for 3 min can quantitatively converted As(III), As(V), MMA and DMA into As(V) at $1 \% \mathrm{~K}_{2} \mathrm{~S}_{2} \mathrm{O}_{8}(w / v)$.

It is noted that the higher chemical valence of analytes would be dominant after the eluted organic compounds are oxidized either via a UV or microwave digestion process. Therefore, a pretreatment to transfer into lower valence compounds is required, that is $\mathrm{As}(\mathrm{V}) \rightarrow \mathrm{As}(\mathrm{III}), \mathrm{Sb}(\mathrm{V}) \rightarrow \mathrm{Sb}(\mathrm{III})$ and $\mathrm{Se}(\mathrm{VI}) \rightarrow \mathrm{Se}(\mathrm{IV})$. For example, As(V) has low HG efficiency, and thus in order to improve the analytical sensitive, an acidic thiourea solution was used on-line by Yu et al. [162] and thioglycolic acid was used by Musil and Matoušek [163] to pre-reduce As(V) prior to HG reaction. However, resulting from the differences in chemical properties of each element and their associated compounds, the reactivity of these different compounds varies greatly. For example, KI can reduce $\mathrm{As}(\mathrm{V})$ and $\mathrm{Sb}(\mathrm{V})$ to $\mathrm{As}(\mathrm{III})$ and $\mathrm{Sb}$ (III) at room temperature, whereas it is impossible to reduce Se(VI) to Se(IV) under the same conditions.

Although there are some reports on the analysis of As, Hg, Se and Sb species by AAS [164-167] or AES [168-170] in recent years, AFS is described to be superior to AAS and similar to ICP-MS regarding sensitivity and linear calibration range for As and Se species in routine analysis. Analytical features such as low detection limits and wide linear calibration ranges, simplicity, lower acquisition and running costs make AFS a suitable atomic detector in speciation studies.

\subsection{Mass Spectrometry Methods}

The unquestionable advantages of ICP-MS over other species detectors are its high sensitivity and multi-element on-line detection capacity. In addition, the application of MS allows not only to obtain the information on the qualitative and quantitative contents of the sample, but also to determine the structure and molar masses of the analytes. The coupling of different separation techniques with ICP-MS has become common practice for the speciation analysis of trace As, $\mathrm{Hg}$, Se and $\mathrm{Sb}[171,172]$. Unlike HG/CV-AFS, no oxidation and pre-reduction steps are required for ICP-MS, unless HG is introduced in the system.

Even though the interface of ICP-MS detector with HPLC is relatively simple, the main problem is that the mobile phase used must be compatible with detection system. Sodium or potassium phosphate buffer mobile phases often utilized in IEC are not appropriate for a MS detector. As discussed above, non-volatile buffer salts can be collected on the lenses and skimmer cones resulting in signal drift and a high maintenance level for cleaning the inner surfaces of the MS detector, and thus the use of 
volatile buffer systems or ones that have low residue is required [97]. Organic modifiers are often used in the mobile phase of RPC, and large volumes of organic solvent reaching the ICP probably results in an unstable plasma. In this sense, methanol is more widely used than acetonitrile for RPC mobile phases $[109,111]$. Meanwhile, desolvation the liquid aerosol before it reaches the ICP, simple flow splitting after the HPLC column, or the use of a small bore or microbore column is also adopted to reduce the amount of organic solvent introduced into the detector $[98,173,174]$.

Although ICP-MS exhibits very good analytical performances for ultra-trace determination, one of its disadvantages is vulnerable to interferences with the molecular ion signals by atomic argon (Ar) and chlorine which can hinder the measurement of Se and As species. For example, when ICP-MS is used as a detector for As determination, it frequently suffers from chloride interference as ${ }^{38} \mathrm{Ar}^{37} \mathrm{Cl}^{+},{ }^{40} \mathrm{Ar}^{35} \mathrm{Cl}^{+}$(the $m / z 75$ is the same as ${ }^{75} \mathrm{As}$ ) are generated if samples contain high amount of chloride $[175,176]$. However, the introduction of ICP-MS equipped with collision/reaction cell (CRC) or dynamic reaction cell (DRC) is an effective approach to overcome these problems linked with polyatomic interferences, among which the DRC technique is introduced by using the reacting gas, such as ammonia, hydrogen, oxygen, etc. The reacting gas overcomes these interferences by atom transfer or charge transfer reactions to break the polyatomic ions into atoms or ions with different $m / z[121,177,178]$. For example, a DRC for spectral interferences elimination by using oxygen and ammonia as reaction gases was developed by Marcinkowska et al. [178] for multielemental speciation analysis of $\mathrm{Cr}(\mathrm{VI})$, As(III) and $\mathrm{As}(\mathrm{V})$ in water by advanced hyphenated technique HPLC/ICP-DRC-MS. Moreover, with the introduction of an additional quadrupole, ICP-tandem MS (ICP-MS/MS) provides more reaction/collision modes for interference elimination $[179,180]$. ICP-MS/MS can be seen as a conventional ICP-CRC-MS unit with an additional quadrupole located before the CRC. Only ions of a given $m / z$ are allowed to enter the CRC, by which it contributes to a better control over the reactions taking place in the cell. For example, arsenic species in seafood were determined by Schmidt et al. [103] by LC-ICP-MS/MS using $\mathrm{O}_{2}$ as reaction gas for the conversion of ${ }^{75} \mathrm{As}$ to ${ }^{75} \mathrm{As}{ }^{16} \mathrm{O}$. ICP-MS/MS was used by Gao et al. [158] for the detection of selenium species in rice after separated by IP-RPC. Two reaction gas modes $\left(\mathrm{H}_{2}, \mathrm{O}_{2}\right)$ and a collision mode $(\mathrm{He})$ were investigated and found that $\mathrm{H}_{2}$ mode was the best choice for eliminating interferences and obtaining a higher signal-to-noise ratio.

MS detection allows the use of isotope dilution analysis (IDA) for speciation analysis due to its specific detection based on the ratio $m / z$ [181]. ID-MS is considered to be an effective method offering accurate determination of elemental species with only small uncertainties. For example, post column isotope dilution with Se-78 spike was performed by Jeong et al. [182] for quantitative speciation of Se in human blood serum and urine. Internal standardization based on the species-unspecific isotope dilution analysis technique was proposed by Castillo et al. [183] to overcome the matrix effects and signal drift originated in the speciation of As in urine, by which it allows the calculation of the corrected overall species concentrations without requiring any methodological calibration. Moreover, in order to avoid the deterioration of sensitivity, accuracy, and long-term stability of system due to the direct introduction of salt- or organic-rich effluent into the instrument, a suitable interfacing technique is highly desirable to couple HPLC with ICP-MS for the detection of elemental species in complex matrices. Accordingly, the generation of volatile analytes by derivatization has been extensively and increasingly reported so as to improve the analytical sensitivity and eliminate the spectral/non-spectral interferences from the sample matrices and effluents $[184,185]$. As stated ahead, online hydride/vapor generation technique can effectively solve this problem. However, the species which can react with $\mathrm{BH}_{4}{ }^{-}$to generation hydride/vapor are limited. For example, it is thought that $\mathrm{Se}(\mathrm{VI})$ is not reducible into hydride according to the studies on the reduction kinetics of inorganic Se species with $\mathrm{NaBH}_{4}$. Consequently, inorganic Se(VI) and Se(IV) analysis by HG technique must be carried out by first determining Se(IV) and then transforming Se(VI) to Se(IV) prior to the determination. Meanwhile, the stability of plasma may worsen when determined by HG-ICP-MS because online HG system delivers not only hydride vapor but also large amounts of hydrogen into the ICP. Therefore, the other alternative vapor generation techniques are developed. For example, an on-line sequential photocatalyst-assisted 
digestion and vaporization device was coupled between LC and ICP-MS by Tsai et al. [186] for Se speciation analysis.

It is noted that although modern techniques using MS detection can help to obtain a better understanding of the experimental data and species identification, many analytical laboratories cannot support such instruments due to their high price and expensive maintenance. Therefore, the hyphenation of chromatography with atomic spectrometry seems to be a well substitute of mass spectrometry.

\section{Conclusion and Perspective}

As far as the separation and detection of element speciation in environmental and biological samples are concerned, different approaches can be used based on on-line or off-line procedures. The hyphenated techniques, in which effective separation methods are coupled on-line with diverse selective and sensitive detectors, are attractive tools in the speciation analysis of $\mathrm{As}, \mathrm{Hg}$, Se and Se. Their main advantages include extremely low limits of detection and quantification, insignificant influence of interferences on the determination process, as well as very high precision and repeatability. Although powerful techniques based on MS are nowadays extensively used for the speciation analysis of trace elements, it is considered as an expensive instrument to purchase and maintain, and only few laboratories can support the high cost of such techniques. The hyphenation of chromatography to atomic spectrometry detectors especially the AFS is still liable and low-cost alternative for routine laboratories. Meanwhile, HG in conjunction with AFS detection deserves more research because it can be hyphenated easily to LC, and provides detection limits of the same order of those obtained with MS techniques. Therefore, it is predictable that HPLC coupled with HG-AFS will be promising for speciation analysis of $\mathrm{As}, \mathrm{Hg}$, Se and $\mathrm{Sb}$ in environmental and biological samples, and has vast potential for further development.

Author Contributions: X.Y. and C.L. contributed to literature search and writing of the manuscript; Y.G. and T.D. revised the manuscript with critical reviews and comments.

Funding: This work was supported by the National Natural Science Foundation of China (grant numbers U1607129, U1607123 and 21773170) and the Yangtze Scholars and Innovative Research Team of the Chinese University (grant number IRT_17R81).

Conflicts of Interest: The authors declare no conflict of interest.

\section{References}

1. Dumout, E.; Vanhaecke, F.; Cornelis, R. Selenium speciation from food source to metabolites: A critical review. Anal. Bioanal. Chem. 2006, 385, 1304-1323. [CrossRef] [PubMed]

2. Vadala, R.; Mottese, A.F.; Bua, G.D.; Salvo, A.; Mallamace, D.; Corsaro, C.; Vasi, S.; Giofre, S.V.; Alfa, M.; Cicero, N.; et al. Statistical analysis of mineral concentration for the geographic identification of garlic samples from Sicily (Italy), Tunisia and Spain. Foods 2016, 5, 20. [CrossRef] [PubMed]

3. Albergamo, A.; Rotondo, A.; Salvo, A.; Pellizzeri, V.; Bua, D.G.; Maggio, A.; Cicero, N.; Dugo, G. Metabolite and mineral profiling of "Violetto di Niscemi" and "Spinoso di Menfi" globe artichokes by H-1-NMR and ICP-MS. Nat. Prod. Res. 2017, 31, 990-999. [CrossRef] [PubMed]

4. Nordberg, M.; Duffus, J.; Templeton, D.M. Glossary of terms used in toxicokinetics (IUPAC Recommendations 2003). Pure Appl. Chem. 2004, 76, 1033-1082. [CrossRef]

5. Templeton, D.M.; Ariese, F.; Cornelis, R.; Danielsson, L.G.; Muntau, H.; van Leeuwen, H.P.; Lobinski, R. Guidelines for terms related to chemical speciation and fractionation of elements. Definitions, structural aspects, and methodological approaches (IUPAC Recommendations 2000). Pure Appl. Chem. 2000, 72, 1453-1470. [CrossRef]

6. Tessier, A.; Campbell, P.G.C.; Bisson, M. Sequential extraction procedure for the speciation of particulate trace metals. Anal. Chem. 1979, 51, 844-851. [CrossRef] 
7. Zhang, S.H.; Wang, Y.; Pervaiz, A.; Kong, L.H.; He, M.C. Comparison of diffusive gradients in thin-films (DGT) and chemical extraction methods for predicting bioavailability of antimony and arsenic to maize. Geoderma 2018, 332, 1-9. [CrossRef]

8. Aguilar-Carrillo, J.; Herrera, L.; Gutierrez, E.J.; Reyes-Dominguez, I.A. Solid-phase distribution and mobility of thallium in mining-metallurgical residues: Environmental hazard implications. Environ. Pollut. 2018, 243, 1833-1845. [CrossRef] [PubMed]

9. Izquierdo, M.; Tye, A.M.; Chenery, S.R. Using isotope dilution assays to understand speciation changes in $\mathrm{Cd}, \mathrm{Zn}, \mathrm{Pb}$ and $\mathrm{Fe}$ in a soil model system under simulated flooding conditions. Geoderma 2017, 295, 41-52. [CrossRef]

10. Salvo, A.; La Torre, G.L.; Mangano, V.; Casale, K.E.; Bartolomeo, G.; Santini, A.; Granata, T.; Dugo, G. Toxic inorganic pollutants in foods from agricultural producing areas of Southern Italy: Level and riskassessment. Ecotoxicol. Environ. Saf. 2018, 148, 114-124. [CrossRef] [PubMed]

11. Kumarathilaka, P.; Seneweera, S.; Meharg, A.; Bundschuh, J. Arsenic speciation dynamics in paddy rice soil-water environment: Sources, physico-chemical, and biological factors-A review. Water Res. 2018, 140, 403-414. [CrossRef] [PubMed]

12. Zhu, S.L.; Zhang, Z.L.; Zagar, D. Mercury transport and fate models in aquatic systems: A review and synthesis. Sci. Total Environ. 2018, 639, 538-549. [CrossRef] [PubMed]

13. Natasha; Shahid, M.; Niazi, N.K.; Khalid, S.; Murtaza, B.; Bibi, I.; Rashid, M.I. A critical review of selenium biogeochemical behavior in soil-plant system with an inference to human health. Environ. Pollut. 2018, 234, 915-934. [CrossRef] [PubMed]

14. Huang, K.; Xu, Y.; Packianathan, C.; Gao, F.; Chen, C.; Zhang, J.; Shen, Q.R.; Rosen, B.P.; Zhao, F.J. Arsenic methylation by a novel ArsM As(III) S-adenosylmethionine methyltransferase that requires only two conserved cysteine residues. Mol. Microbiol. 2018, 107, 265-276. [CrossRef] [PubMed]

15. Lazaro, W.L.; Diez, S.; da Silva, C.J.; Ignacio, A.R.A.; Guimaraes, J.R.D. Seasonal changes in peryphytic microbial metabolism determining mercury methylation in a tropical wetland. Sci. Total Environ. 2018, 627, 1345-1352. [CrossRef]

16. Ruszczynska, A.; Konopka, A.; Kurek, E.; Elguera, J.C.T.; Bulska, E. Investigation of biotransformation of selenium in plants using spectrometric methods. Spectrochim. Acta B 2017, 130, 7-16. [CrossRef]

17. Takahashi, K.; Suzuki, N.; Ogra, Y. Effect of administration route and dose on metabolism of nine bioselenocompounds. J. Trace Elem. Med. Biol. 2018, 49, 113-118. [CrossRef] [PubMed]

18. Terol, A.; Ardini, F.; Basso, A.; Grotti, M. Determination of selenium urinary metabolites by high temperature liquid chromatography-inductively coupled plasma mass spectrometry. J. Chromatogr. A 2015, 1380, 112-119. [CrossRef] [PubMed]

19. Amayo, K.O.; Raab, A.; Krupp, E.M.; Feldmann, J. Identification of arsenolipids and their degradation products in cod-liver oil. Talanta 2014, 118, 217-223. [CrossRef] [PubMed]

20. Sele, V.; Sloth, J.J.; Holmelid, B.; Valdersnes, S.; Skov, K.; Amlund, H. Arsenic-containing fatty acids and hydrocarbons in marine oils-Determination using reversed-phase HPLC-ICP-MS and HPLC-qTOE-MS. Talanta 2014, 121, 89-96. [CrossRef] [PubMed]

21. Rumpler, A.; Edmonds, J.S.; Katsu, M.; Jensen, K.B.; Goessler, W.; Raber, G.; Gunnlaugsdottir, H.; Francesconi, K.A. Arsenic-containing long-chain fatty acids in cod-liver oil: A result of biosynthetic infidelity? Angew. Chem. Int. Ed. 2008, 47, 2665-2667. [CrossRef] [PubMed]

22. Contreras-Acuña, M.; García-Barrera, T.; García-Sevillano, M.A.; Gómez-Ariza, J.L. Speciation of arsenic in marine food (Anemonia sulcata) by liquid chromatography coupled to inductively coupled plasma mass spectrometry and organic mass spectrometry. J. Chromatogr. A 2013, 1282, 133-141. [CrossRef] [PubMed]

23. Peng, H.Y.; Hu, B.; Liu, Q.Q.; Yang, Z.L.; Lu, X.F.; Huang, R.F.; Li, X.F.; Zuidhof, M.J.; Le, X.C. Liquid chromatography combined with atomic and molecular mass spectrometry for speciation of arsenic in chicken liver. J. Chromatogr. A 2014, 1370, 40-49. [CrossRef] [PubMed]

24. Kot, A.; Namiesnik, J. The role of speciation in analytical chemistry. TrAC-Trend Anal. Chem. 2000, 19, 69-79. [CrossRef]

25. Sadee, B.; Foulkes, M.E.; Hill, S.J. Coupled techniques for arsenic speciation in food and drinking water: A review. J. Anal. Atom. Spectrom. 2015, 30, 102-118. [CrossRef]

26. Nearing, M.M.; Koch, I.; Reimer, K.J. Complementary arsenic speciation methods: A review. Spectrochim. Acta B 2014, 99, 150-162. [CrossRef] 
27. Huber, J.; Leopold, K. Nanomaterial-based strategies for enhanced mercury trace analysis in environmental and drinking waters. TrAC-Trend Anal. Chem. 2016, 80, 280-292. [CrossRef]

28. Amde, M.; Yin, Y.G.; Zhang, D.; Liu, J.F. Methods and recent advances in speciation analysis of mercury chemical species in environmental samples: A review. Chem. Speciat. Bioavailab. 2016, 28, 51-65. [CrossRef]

29. Pyrzynska, K.; Sentkowska, A. Liquid chromatographic analysis of selenium species in plant materials. TrAC-Trend Anal. Chem. 2019, 111, 128-138. [CrossRef]

30. Pettine, M.; McDonald, T.J.; Sohn, M.; Anquandah, G.A.K.; Zboril, R.; Sharma, V.K. A critical review of selenium analysis in natural water samples. Trends Environ. Anal. 2015, 5, 1-7. [CrossRef]

31. Ferreira, S.L.C.; dos Anjos, J.P.; Felix, C.S.A.; da Silva, M.M.; Palacio, E.; Cerda, V. Speciation analysis of antimony in environmental samples employing atomic fluorescence spectrometry-Review. TrAC-Trend Anal. Chem. 2019, 110, 335-343. [CrossRef]

32. Miravet, R.; Hernandez-Nataren, E.; Sahuquillo, A.; Rubio, R.; Lopez-Sanchez, J.F. Speciation of antimony in environmental matrices by coupled techniques. TrAC-Trend Anal. Chem. 2010, 29, 28-39. [CrossRef]

33. Carvalho, D.C.; Coelho, N.M.M.; Melo Coelho, L.; Borges, S.S.S.; Neri, T.S.; Alves, V.N. Strategies to increase selectivity of analytical methods for As, $\mathrm{Cr}$ and Se speciation in biological samples: A review. Sample Prep. 2014, 2, 1-12. [CrossRef]

34. Vieira, M.A.; Grinberg, P.; Bobeda, C.R.R.; Reyes, M.N.M.; Campos, R.C. Non-chromatographic atomic spectrometric methods in speciation analysis: A review. Spectrochim. Acta B 2009, 64, 459-476. [CrossRef]

35. Gonzalvez, A.; Cervera, M.L.; Armenta, S.; de la Guardia, M. A review of non-chromatographic methods for speciation analysis. Anal. Chim. Acta 2009, 636, 129-157. [CrossRef] [PubMed]

36. Ibrahim, A.S.A.; Al-Farawati, R.; Hawas, U.; Shaban, Y. Recent microextraction techniques for determination and chemical speciation of selenium. Open Chem. 2017, 15, 103-122. [CrossRef]

37. Werner, J.; Grzeskowiak, T.; Zgola-Grzeskowiak, A.; Stanisz, E. Recent trends in microextraction techniques used in determination of arsenic species. TrAC-Trend Anal. Chem. 2018, 105, 121-136. [CrossRef]

38. Pena-Pereira, F.; Lavilla, I.; Bendicho, C. Miniaturized preconcentration methods based on liquid-liquid extraction and their application in inorganic ultratrace analysis and speciation: A review. Spectrochim. Acta B 2009, 64, 1-15. [CrossRef]

39. Panhwar, A.H.; Tuzen, M.; Kazi, T.G. Ultrasonic assisted dispersive liquid-liquid microextraction method based on deep eutectic solvent for speciation, preconcentration and determination of selenium species (IV) and (VI) in water and food samples. Talanta 2017, 175, 352-358. [CrossRef] [PubMed]

40. Akramipour, R.; Golpayegani, M.R.; Gheini, S.; Fattahi, N. Speciation of organic/inorganic mercury and total mercury in blood samples using vortex assisted dispersive liquid-liquid microextraction based on the freezing of deep eutectic solvent followed by GFAAS. Talanta 2018, 186, 17-23. [CrossRef] [PubMed]

41. Haghnazari, L.; Mirzaei, N.; Arfaeinia, H.; Karimyan, K.; Sharafi, H.; Fattahi, N. Speciation of As(III)/As(V) and total inorganic arsenic in biological fluids using new mode of liquid-phase microextraction and electrothermal atomic absorption spectrometry. Biol. Trace Elem. Res. 2018, 183, 173-181. [CrossRef] [PubMed]

42. Zeng, C.J.; Yan, Y.Y.; Tang, J.; Wu, Y.H.; Zhong, S.S. Speciation of Arsenic(III) and Arsenic(V) based on Triton X-100 hollow fiber liquid phase microextraction coupled with flame atomic absorption spectrometry. Spectrosc. Lett. 2017, 50, 220-226. [CrossRef]

43. Turker, A.R. Speciation of trace metals and metalloids by solid phase extraction with spectrometric detection: A critical review. Turk. J. Chem. 2016, 40, 847-867. [CrossRef]

44. Su, C.K.; Chen, W.C. 3D-printed, $\mathrm{TiO}_{2}$ NP-incorporated minicolumn coupled with ICP-MS for speciation of inorganic arsenic and selenium in high-salt-content samples. Microchim. Acta 2018, 185, 1-8. [CrossRef] [PubMed]

45. Panhwar, A.H.; Tuzen, M.; Hazer, B.; Kazi, T.G. Solid phase microextraction method using a novel polystyrene oleic acid imidazole polymer in micropipette tip of syringe system for speciation and determination of antimony in environmental and food samples. Talanta 2018, 184, 115-121. [CrossRef] [PubMed]

46. Wang, H.; Hen, B.B.; Zhu, S.Q.; Yu, X.X.; He, M.; Hu, B. Chip-based magnetic solid-phase microextraction online coupled with micro HPLC-ICP-MS for the determination of mercury species in cells. Anal. Chem. 2016, 88, 796-802. [CrossRef] [PubMed] 
47. Ali, J.; Tuzen, M.; Kazi, T.G.; Hazer, B. Inorganic arsenic speciation in water samples by miniaturized solid phase microextraction using a new polystyrene polydimethyl siloxane polymer in micropipette tip of syringe system. Talanta 2016, 161, 450-458. [CrossRef] [PubMed]

48. Nyaba, L.; Matong, J.M.; Dimpe, K.M.; Nomngongo, P.N. Speciation of inorganic selenium in environmental samples after suspended dispersive solid phase microextraction combined with inductively coupled plasma spectrometric determination. Talanta 2016, 159, 174-180. [CrossRef] [PubMed]

49. Fan, Z.F. Determination of antimony(III) and total antimony by single-drop microextraction combined with electrothermal atomic absorption spectrometry. Anal. Chim. Acta 2007, 585, 300-304. [CrossRef] [PubMed]

50. Tolessa, T.; Tan, Z.Q.; Yin, Y.G.; Liu, J.F. Single-drop gold nanoparticles for headspace microextraction and colorimetric assay of mercury (II) in environmental waters. Talanta 2018, 176, 77-84. [CrossRef] [PubMed]

51. Jia, X.Y.; Zhao, J.Y.; Ren, H.Y.; Wang, J.N.; Hong, Z.X.; Zhang, X. Zwitterion-functionalized polymer microspheres-based solid phase extraction method on-line combined with HPLC-ICP-MS for mercury speciation. Talanta 2019, 196, 592-599. [CrossRef] [PubMed]

52. Londonio, A.; Hasuoka, P.E.; Pacheco, P.; Gil, R.A.; Smichowski, P. Online solid phase extractionHPLC-ICP-MS system for mercury and methylmercury preconcentration using functionalised carbon nanotubes for their determination in dietary supplements. J. Anal. Atom. Spectrom. 2018, 33, 1737-1744. [CrossRef]

53. Li, P.; Chen, Y.J.; Hu, X.; Lian, H.Z. Magnetic solid phase extraction for the determination of trace antimony species in water by inductively coupled plasma mass spectrometry. Talanta 2015, 134, 292-297. [CrossRef] [PubMed]

54. Zhang, L.; Morita, Y.; Sakuragawa, A.; Isozaki, A. Inorganic speciation of As(III, V), Se(IV, VI) and Sb(III, V) in natural water with GF-AAS using solid phase extraction technology. Talanta 2007, 72, 723-729. [CrossRef] [PubMed]

55. Peng, H.Y.; Zhang, N.; He, M.; Chen, B.B.; Hu, B. Simultaneous speciation analysis of inorganic arsenic, chromium and selenium in environmental waters by 3-(2-aminoethylamino) propyltrimethoxysilane modified multi-wall carbon nanotubes packed microcolumn solid phase extraction and ICP-MS. Talanta 2015, 131, 266-272. [CrossRef] [PubMed]

56. Zhao, L.Y.; Zhu, Q.Y.; Mao, L.; Chen, Y.J.; Lian, H.Z.; Hu, X. Preparation of thiol- and amine-bifunctionalized hybrid monolithic column via "one-pot" and applications in speciation of inorganic arsenic. Talanta 2019, 192, 339-346. [CrossRef] [PubMed]

57. Zheng, C.B.; Hu, L.G.; Hou, X.D.; He, B.; Jiang, G.B. Headspace solid-phase microextraction coupled to miniaturized microplasma optical emission spectrometry for detection of mercury and lead. Anal. Chem. 2018, 90, 3683-3691. [CrossRef] [PubMed]

58. Yang, Y.; Tan, Q.; Lin, Y.; Tian, Y.F.; Wu, L.; Hou, X.D.; Zheng, C.B. Point discharge optical emission spectrometer as a gas chromatography (GC) detector for speciation analysis of mercury in human hair. Anal. Chem. 2018, 90, 11996-12003. [CrossRef] [PubMed]

59. Lin, Y.; Yang, Y.; Li, Y.X.; Yang, L.; Hou, X.D.; Feng, X.B.; Zheng, C.B. Ultrasensitive speciation analysis of mercury in rice by headspace solid phase microextraction using porous carbons and gas chromatography-dielectric barrier discharge optical emission spectrometry. Environ. Sci. Technol. 2016, 50, 2468-2476. [CrossRef] [PubMed]

60. Mester, Z. Gas phase sampling of volatile (organo)metallic compounds above solid samples. J. Anal. Atom. Spectrom. 2002, 17, 868-871. [CrossRef]

61. Zhang, W.F.; Hu, Y.A.; Cheng, H.F. Optimization of microwave-assisted extraction for six inorganic and organic arsenic species in chicken tissues using response surface methodology. J. Sep. Sci. 2015, 38, 3063-3070. [CrossRef] [PubMed]

62. Zounr, R.A.; Tuzen, M.; Khuhawar, M.Y. Ultrasound assisted deep eutectic solvent based on dispersive liquid liquid microextraction of arsenic speciation in water and environmental samples by electrothermal atomic absorption spectrometry. J. Mol. Liq. 2017, 242, 441-446. [CrossRef]

63. Shirkhanloo, H.; Khaligh, A.; Mousavi, H.Z.; Rashidi, A. Ultrasound assisted-dispersive-ionic liquid-micro-solid phase extraction based on carboxyl-functionalized nanoporous graphene for speciation and determination of trace inorganic and organic mercury species in water and caprine blood samples. Microchim. J. 2017, 130, 245-254. [CrossRef] 
64. Altunay, N.; Gurkan, R. Separation/preconcentration of ultra-trace levels of inorganic Sb and Se from different sample matrices by charge transfer sensitized ion-pairing using ultrasonic-assisted cloud point extraction prior to their speciation and determination by hydride generation AAS. Talanta 2016, 159, 344-355. [PubMed]

65. Lou, C.G.; Liu, W.Q.; Liu, X.D. Quantitative analysis of arsenic speciation in guano and ornithogenic sediments using microwave-assisted extraction followed by high-performance liquid chromatography coupled to hydride generation atomic fiuorescence spectrometry. J. Chromatogr. B 2014, 969, 29-34. [CrossRef] [PubMed]

66. Saucedo-Velez, A.A.; Hinojosa-Reyes, L.; Villanueva-Rodriguez, M.; Caballero-Quintero, A.; Hernandez-Ramirez, A.; Guzman-Mar, J.L. Speciation analysis of organoarsenic compounds in livestock feed by microwave-assisted extraction and high performance liquid chromatography coupled to atomic fluorescence spectrometry. Food Chem. 2017, 232, 493-500. [CrossRef] [PubMed]

67. Cao, Y.P.; Yan, L.Z.; Huang, H.L.; Deng, B.Y. Selenium speciation in radix puerariae using ultrasonic assisted extraction combined with reversed phase high performance liquid chromatography-inductively coupled plasma-mass spectrometry after magnetic solid-phase extraction with 5-sulfosalicylic acid functionalized magnetic nanoparticles. Spectrochim. Acta B 2016, 122, 172-177.

68. Musil, S.; Petursdottir, A.H.; Raab, A.; Gunnlaugsdottir, H.; Krupp, E.; Feldmann, J. Speciation without chromatography using selective hydride generation: Inorganic arsenic in rice and samples of marine origin. Anal. Chem. 2014, 86, 993-999. [CrossRef] [PubMed]

69. Welna, M.; Pohl, P. Potential of the hydride generation technique coupled to inductively coupled plasma optical emission spectrometry for non-chromatographic As speciation. J. Anal. Atom. Spectrom. 2017, 32, 1766-1779. [CrossRef]

70. Hu, P.Y.; Wang, X.; Yang, L.; Yang, H.Y.; Tang, Y.Y.; Luo, H.; Xiong, X.L.; Jiang, X.; Huang, K. Speciation of mercury by hydride generation ultraviolet atomization-atomic fluorescence spectrometry without chromatographic separation. Microchem. J. 2018, 143, 228-233. [CrossRef]

71. Vieira, M.A.; Ribeiro, A.S.; Curtius, A.J.; Sturgeon, R.E. Determination of total mercury and methylmercury in biological samples by photochemical vapor generation. Anal. Bioanal. Chem. 2007, 388, 837-847. [CrossRef] [PubMed]

72. Mendez, H.; Lavilla, I.; Bendicho, C. Mild sample pretreatment procedures based on photolysis and sonolysis-promoted redox reactions as a new approach for determination of Se(IV), Se(VI) and Se(-II) in model solutions by the hydride generation technique with atomic absorption and fluorescence detection. J. Anal. Atom. Spectrom. 2004, 19, 1379-1385.

73. Chen, Y.W.; Zhou, M.D.; Tong, J.; Belzile, N. Application of photochemical reactions of Se in natural waters by hydride generation atomic fluorescence spectrometry. Anal. Chim. Acta 2005, 545, 142-148. [CrossRef]

74. Chen, Y.W.; Zhou, X.L.; Tong, J.; Truong, Y.; Belzile, N. Photochemical behavior of inorganic and organic selenium compounds in various aqueous solutions. Anal. Chim. Acta 2005, 545, 149-157. [CrossRef]

75. Shuvaeva, O.V.; Gustaytis, M.A.; Anoshin, G.N. Mercury speciation in environmental solid samples using thermal release technique with atomic absorption detection. Anal. Chim. Acta 2008, 621, 148-154. [CrossRef] [PubMed]

76. Kaercher, L.E.; Goldschmidt, F.; Paniz, J.N.G.; Flores, É.M.M.; Dressler, V.L. Determination of inorganic and total mercury by vapor generation atomic absorption spectrometry using different temperatures of the measurement cell. Spectrochim. Acta Part B 2005, 60, 705-710. [CrossRef]

77. Liao, M.X.; Deng, T.L. Arsenic species analysis in porewaters and sediments using hydride generation atomic fluorescence spectrometry. J. Environ. Sci. 2006, 18, 995-999. [CrossRef]

78. Xi, J.C.; He, M.C.; Wang, K.P.; Zhang, G.Z. Comparison of masking agents for antimony speciation analysis using hydride generation atomic fluorescence spectrometry. Front. Environ. Sci. Eng. 2015, 9, 970-978. [CrossRef]

79. Teran-Baamonde, J.; Bouchet, S.; Tessier, E.; Amouroux, D. Development of a large volume injection method using a programmed temperature vaporization injector-gas chromatography hyphenated to ICP-MS for the simultaneous determination of mercury, tin and lead species at ultra-trace levels in natural waters. J. Chromatogr. A 2018, 1547, 77-85. [CrossRef] [PubMed] 
80. Giraaldez, I.; Ruiz-Azcona, P.; Vidal, A.; Morales, E. Speciation of selenite and selenoamino acids in biota samples bdual stir bar sorptive extraction-single desorption-capillary gas chromatography/mass spectrometry. Microchim. J. 2015, 122, 197-204. [CrossRef]

81. Rahman, G.M.M.; Wolle, M.M.; Fahrenholz, T.; Kingston, H.M.; Pamuku, M. Measurement of mercury species in whole blood using speciated isotope dilution methodology integrated with microwave-enhanced solubilization and spike equilibration, headspace-solid-phase microextraction, and GC-ICP-MS analysis. Anal. Chem. 2014, 86, 6130-6137. [CrossRef] [PubMed]

82. Gajdosechova, Z.; Pagliano, E.; Zborowski, A.; Mester, Z. Headspace in-tube microextraction and GC-ICP-MS determination of mercury species in petroleum hydrocarbons. Energy Fuels 2018, 32, 10493-10501. [CrossRef]

83. Cai, Y.; Monsalud, S.; Jaffé, R.; Jones, R.D. Gas chromatographic determination of organomercury following aqueous derivatization with sodium tetraethylborate and sodium tetraphenylborate: Comparative study of gas chromatography coupled with atomic fluorescence spectrometry, atomic emission spectrometry and mass spectrometry. J. Chromatogr. A 2000, 876, 147-155. [PubMed]

84. Nevado, J.J.B.; Martín-Doimeadios, R.C.R.; Krupp, E.M.; Bernardo, F.J.G.; Fariñas, N.R.; Moreno, M.J.; Wallace, D.; Ropero, M.J.P. Comparison of gas chromatographic hyphenated techniques for mercury speciation analysis. J. Chromatogr. A 2011, 1218, 4545-4551. [CrossRef] [PubMed]

85. Jung, M.Y.; Kang, J.H.; Jung, H.J.; Ma, S.Y. Inorganic arsenic contents in ready-to-eat rice products and various Korean rice determined by a highly sensitive gas chromatography-tandem mass spectrometry. Food Chem. 2018, 240, 1179-1183. [CrossRef] [PubMed]

86. Kang, J.H.; Jung, H.J.; Jung, M.Y. One step derivatization with British Anti-Lewsite in combination with gas chromatography coupled to triple-quadrupole tandem mass spectrometry for the fast and selective analysis of inorganic arsenic in rice. Anal. Chim. Acta 2016, 934, 231-238. [CrossRef] [PubMed]

87. Gionfriddo, E.; Naccarato, A.; Sindona, G.; Tagarelli, A. A reliable solid phase microextraction-gas chromatography-triple quadrupole mass spectrometry method for the assay of selenomethionine and selenomethylselenocysteine in aqueous extracts: Difference between selenized and not-enriched selenium potatoes. Anal. Chim. Acta 2012, 747, 58-66. [CrossRef] [PubMed]

88. Ghasemi, E.; Sillanpaa, M.; Najafi, N.M. Headspace hollow fiber protected liquid-phase microextraction combined with gas chromatography-mass spectroscopy for speciation and determination of volatile organic compounds of selenium in environmental and biological samples. J. Chromatogr. A 2011, 118, 380-386. [CrossRef] [PubMed]

89. Smith, L.M.; Maher, W.A.; Craig, P.J.; Jenkins, R.O. Speciation of volatile antimony compounds in culture headspace gases of Cryptococcus humicolus using solid phase microextraction and gas chromatography-mass spectrometry. Appl. Organomet. Chem. 2002, 16, 287-293. [CrossRef]

90. Rekhi, H.; Rani, S.; Sharma, N.; Malik, A.K. A review on recent applications of high-performance liquid chromatography in metal determination and speciation analysis. Crit. Rev. Anal. Chem. 2017, 47, 524-537. [CrossRef] [PubMed]

91. Son, S.H.; Lee, W.B.; Kim, D.; Lee, Y.; Nam, S.H. An alternative analytical method for determining arsenic species in rice by using ion chromatography and inductively coupled plasma-mass spectrometry. Food Chem. 2019, 270, 353-358. [CrossRef] [PubMed]

92. Shi, Q.L.; Ju, M.Y.; Zhu, X.X.; Gan, H.; Gu, R.L.; Wu, Z.N.; Meng, Z.Y.; Dou, G.F. Pharmacokinetic properties of arsenic species after intravenous and intragastrical administration of arsenic trioxide solution in cynomolgus macaques using HPLC-ICP-MS. Molecules 2019, 24, 241. [CrossRef] [PubMed]

93. Guo, L.X.; Zhang, G.W.; Wang, J.T.; Zhong, Y.P.; Huang, Z.G. Determination of arsenic species in ophiocordyceps sinensis from major habitats in China by HPLC-ICP-MS and the edible hazard assessment. Molecules 2018, 23, 1012. [CrossRef] [PubMed]

94. Cui, S.; Kim, C.K.; Lee, K.S.; Min, H.S.; Lee, J.H. Study on the analytical method of arsenic species in marine samples by ion chromatography coupled with mass spectrometry. Microchem. J. 2018, 143, 16-20. [CrossRef]

95. Doker, S.; Yilmaz, M. Speciation of arsenic in spring, well, and tap water by high-performance liquid chromatography-inductively coupled plasma-mass spectrometry. Anal. Lett. 2018, 51, 254-264. [CrossRef]

96. Yu, H.M.; Du, H.; Wu, L.; Li, R.L.; Sun, Q.; Hou, X.D. Trace arsenic speciation analysis of bones by high performance liquid chromatography-inductively coupled plasma mass spectrometry. Microchim. J. 2018, 141, 176-180. [CrossRef] 
97. Zhao, F.; Liu, Y.M.; Zhang, X.Q.; Dong, R.; Yu, W.J.; Liu, Y.F.; Guo, Z.M.; Liang, X.M.; Zhu, J.H. Enzyme-assisted extraction and liquid chromatography-inductively coupled plasma mass spectrometry for the determination of arsenic species in fish. J. Chromatogr. A 2018, 1573, 48-58. [CrossRef] [PubMed]

98. Cheng, H.Y.; Shen, L.H.; Liu, J.H.; Xu, Z.G.; Wang, Y.C. Coupling nanoliter high-performance liquid chromatography to inductively coupled plasma mass spectrometry for arsenic speciation. J. Sep. Sci. 2018, 41, 1524-1531. [CrossRef] [PubMed]

99. Schmidt, L.; Landero, J.A.; Novo, D.L.; Duarte, F.A.; Mesko, M.F.; Caruso, J.A.; Flores, E.M.M. A feasible method for As speciation in several types of seafood by LC-ICP-MS/MS. Food Chem. 2018, 255, 340-347. [CrossRef] [PubMed]

100. Esperanza, M.G.; Barrientos, E.Y.; Wrobel, K.; Aguilar, F.J.A.; Escobosa, A.R.; Wrobel, K. Determination of total arsenic and speciation analysis in Mexican maize tortillas by hydride generation-microwave plasma atomic emission spectrometry and high performance liquid chromatography-inductively coupled plasma-mass spectrometry. Anal. Methods 2017, 9, 2059-2068. [CrossRef]

101. Chen, S.Z.; Guo, Q.Z.; Liu, L.P. Determination of arsenic species in edible mushrooms by high-performance liquid chromatography coupled to inductively coupled plasma mass spectrometry. Food Anal. Method 2017, 10, 740-748. [CrossRef]

102. Han, T.T.; Ji, H.W.; Li, H.X.; Cui, H.; Song, T.; Duan, X.J.; Zhu, Q.L.; Cai, F.; Zhang, L. Speciation analysis of arsenic compounds in seafood by ion chromatography-atomic fluorescence spectrometry. J. Ocean Univ. China 2017, 16, 455-460. [CrossRef]

103. Schmidt, L.; Landero, J.A.; Santos, R.F.; Mesko, M.F.; Mello, P.A.; Flores, E.M.M.; Caruso, J.A. Arsenic speciation in seafood by LC-ICP-MS/MS: Method development and influence of culinary treatment. J. Anal. Atom. Spectrom. 2017, 32, 1490-1499. [CrossRef]

104. Firat, M.; Bakirdere, S.; Sel, S.; Chormey, D.S.; Elkiran, O.; Erulas, F.; Turak, F. Arsenic speciation in water and biota samples at trace levels by ion chromatography inductively coupled plasma-mass spectrometry. Int. J. Environ. Anal. Chem. 2017, 97, 684-693. [CrossRef]

105. Lin, C.H.; Chen, Y.; Su, Y.A.; Luo, Y.T.; Shih, T.T.; Sun, Y.C. Nanocomposite-coated microfluidic-based photocatalyst-assisted reduction device to couple high-performance liquid chromatography and inductively coupled plasma-mass spectrometry for online determination of inorganic arsenic species in natural water. Anal. Chem. 2017, 89, 5892-5900. [CrossRef] [PubMed]

106. Ozcan, S.; Bakirdere, S.; Ataman, O.Y. Speciation of arsenic in fish by high-performance liquid chromatography-inductively coupled plasma-mass spectrometry. Anal. Lett. 2016, 49, 2501-2512. [CrossRef]

107. Jia, X.Y.; Gong, D.R.; Wang, J.N.; Huang, F.Y.; Duan, T.C.; Zhang, X. Arsenic speciation in environmental waters by a new specific phosphine modified polymer microsphere preconcentration and HPLC-ICP-MS determination. Talanta 2016, 160, 437-443. [CrossRef] [PubMed]

108. Gao, X.S.; Dai, J.Y.; Zhao, H.Y.; Zhu, J.; Luo, L.; Zhang, R.; Zhang, Z.; Li, L. Synthesis of MoS 2 nanosheets for mercury speciation analysis by HPLC-UV-HG-AFS. RSC Adv. 2018, 8, 18364-18371. [CrossRef]

109. Liu, H.; Luo, J.Y.; Ding, T.; Gu, S.Y.; Yang, S.H.; Yang, M.H. Speciation analysis of trace mercury in sea cucumber species of apostichopus japonicus using high-performance liquid chromatography Conjunction with inductively coupled plasma mass spectrometry. Biol. Trace Elem. Res. 2018, 186, 554-561. [CrossRef] [PubMed]

110. Liu, Y.M.; Zhang, F.P.; Jiao, B.Y.; Rao, J.Y.; Leng, G. Automated dispersive liquid-liquid microextraction coupled to high performance liquid chromatography-cold vapour atomic fluorescence spectroscopy for the determination of mercury species in natural water samples. J. Chromatogr. A 2017, 1493, 1-9. [CrossRef] [PubMed]

111. Yao, C.H.; Jiang, S.J.; Sahayam, A.C.; Huang, Y.L. Speciation of mercury in fish oils using liquid chromatography inductively coupled plasma mass spectrometry. Microchem. J. 2017, 133, 556-560. [CrossRef]

112. Zhu, S.Q.; Chen, B.B.; He, M.; Huang, T.; Hu, B. Speciation of mercury in water and fish samples by HPLC-ICP-MS after magnetic solid phase extraction. Talanta 2017, 171, 213-219. [CrossRef] [PubMed]

113. Li, L.; Wang, Z.H.; Zhang, S.X.; Wang, M.L. Directly-thiolated graphene based organic solvent-free cloud point extraction-like method for enrichment and speciation of mercury by HPLC-ICP-MS. Microchem. J. 2017, 132, 299-307. [CrossRef]

114. Zhang, S.X.; Luo, H.; Zhang, Y.Y.; Li, X.Y.; Liu, J.S.; Xu, Q.; Wang, Z.H. In situ rapid magnetic solid-phase extraction coupled with HPLC-ICP-MS for mercury speciation in environmental water. Microchem. J. 2016, 126, 25-31. [CrossRef] 
115. Fang, Y.; Pan, Y.S.; Li, P.; Xue, M.; Pei, F.; Yang, W.J.; Ma, N.; Hu, Q.H. Simultaneous determination of arsenic and mercury species in rice by ion-pairing reversed phase chromatography with inductively coupled plasma mass spectrometry. Food Chem. 2016, 213, 609-615. [CrossRef] [PubMed]

116. Le Roux, S.; Baker, P.; Crouch, A. Determination of mercury in selected polluted sediments using HPLC-ICP-MS in Westbank Area, Western Cape, South Africa. S. Afr. J. Chem. 2016, 69, 124-131. [CrossRef]

117. Bakirdere, S.; Volkan, M.; Ataman, O.Y. Selenium speciation in chicken breast samples from inorganic and organic selenium fed chickens using high performance liquid chromatography-inductively coupled plasma-mass spectrometry. J. Food Compos. Anal. 2018, 71, 28-35. [CrossRef]

118. Hu, T.; Liu, L.P.; Chen, S.Z.; Wu, W.L.; Xiang, C.G.; Guo, Y.B. Determination of selenium species in cordyceps militaris by high-performance liquid chromatography coupled to hydride generation atomic fluorescence spectrometry. Anal. Lett. 2018, 51, 2316-2330. [CrossRef]

119. Gao, H.H.; Chen, M.X.; Hu, X.Q.; Chai, S.S.; Qin, M.L.; Cao, Z.Y. Separation of selenium species and their sensitive determination in rice samples by ion-pairing reversed-phase liquid chromatography with inductively coupled plasma tandem mass spectrometry. J. Sep. Sci. 2018, 41, 432-439. [CrossRef] [PubMed]

120. Yazdi, M.; Yamini, Y. Inorganic selenium speciation in water and biological samples by three phase hollow fiber-based liquid phase microextraction coupled with HPLC-UV. New J. Chem. 2017, 41, 2378-2385. [CrossRef]

121. Wiktor, L.; Barbara, M.; Dariusz, K.; Piotr, K.; Danuta, B. Study on Speciation of As, Cr, and Sb in bottled flavored drinking water samples using advanced analytical techniques IEC/SEC-HPLC/ICP-DRC-MS and ESI-MS/MS. Molecules 2019, 24, 668. [CrossRef]

122. Marcinkowska, M.; Lorenc, W.; Baralkiewicz, D. Study of the impact of bottles material and color on the presence of As-III, As-V, Sb-III, Sb-V and Cr-VI in matrix-rich mineral water-Multielemental speciation analysis by HPLC/ICP-DRC-MS. Microchem. J. 2017, 132, 1-7. [CrossRef]

123. Lin, Y.A.; Jiang, S.J.; Sahayam, A.C. Determination of antimony compounds in waters and juices using ion chromatography-inductively coupled plasma mass spectrometry. Food Chem. 2017, 230, 76-81. [CrossRef] [PubMed]

124. Marcinkowska, M.; Komorowicz, I.; Barałkiewicz, D. New procedure for multielemental speciation analysis of five toxic species: $\mathrm{As}(\mathrm{III}), \mathrm{As}(\mathrm{V}), \mathrm{Cr}(\mathrm{VI}), \mathrm{Sb}(\mathrm{III})$ and $\mathrm{Sb}(\mathrm{V})$ in drinking water samples by advanced hyphenated technique HPLC/ICP-DRC-MS. Anal. Chim. Acta 2016, 920, 102-111. [CrossRef] [PubMed]

125. Quiroz, W.; Astudillo, F.; Bravo, M.; Cereceda-Balic, F.; Vidal, V.; Palomo-Marin, M.R.; Rueda-Holgado, F.; Pinilla-Gil, E. Antimony speciation in soils, sediments and volcanic ashes by microwave extraction and HPLC-HG-AFS detection. Microchem. J. 2016, 129, 111-116. [CrossRef]

126. Jablonska-Czapla, M.; Szopa, S. Arsenic, antimony and chromium speciation using HPLC-ICP-MS in selected river ecosystems of Upper Silesia, Poland-A preliminary study and validation of methodology. Water Sci. Technol.-Water Supply 2016, 16, 354-361. [CrossRef]

127. Wei, C.J.; Liu, J.X. A new hydride generation system applied in determination of arsenic species with ion chromatography-hydride generation-atomic fluorescence spectrometry (IC-HG-AFS). Talanta 2007, 73, 540-545. [CrossRef] [PubMed]

128. Chen, X.P.; Han, C.; Cheng, H.Y.; Wang, Y.C.; Liu, J.H.; Xua, Z.G.; Hu, L. Rapid speciation analysis of mercury in seawater and marine fish by cation exchange chromatography hyphenated with inductively coupled plasma mass spectrometry. J. Chromatogr. A 2013, 1314, 86-93. [CrossRef] [PubMed]

129. Zhang, Q.H.; Yanga, G.P. Selenium speciation in bay scallops by high performance liquid chromatography separation and inductively coupled plasma mass spectrometry detection after complete enzymatic extraction. J. Chromatogr. A 2014, 1325, 83-91. [CrossRef] [PubMed]

130. Schaeffer, R.; Soeroes, C.; Ipolyi, I.; Fodor, P.; Thomaidis, N.S. Determination of arsenic species in seafood samples from the Aegean Sea by liquid chromatography-(photo-oxidation)-hydride generation-atomic fluorescence spectrometry. Anal. Chim. Acta 2005, 547, 109-118. [CrossRef]

131. Sánchez-Rodas, D.; Mellano, F.; Martínez, F.; Palencia, P.; Giráldez, I.; Morales, E. Speciation analysis of Se-enriched strawberries (Fragaria ananassa Duch) cultivated on hydroponics by HPLC-TR-HG-AFS. Microchem. J. 2016, 127, 120-124. [CrossRef]

132. Chu, Y.L.; Jiang, S.J. Speciation analysis of arsenic compounds in edible oil by ion chromatography-inductively coupled plasma mass spectrometry. J. Chromatogr. A 2011, 1218, 5175-5179. [CrossRef] [PubMed] 
133. Wolle, M.M.; Rahman, G.M.M.; Kingston, H.M.; Pamuku, M. Speciation analysis of arsenic in prenatal and children's dietary supplements using microwave-enhanced extraction and ion chromatography-inductively coupled plasma mass spectrometry. Anal. Chim. Acta 2014, 818, 23-31. [CrossRef] [PubMed]

134. Wojcieszek, J.; Kwiatkowski, P.; Ruzik, L. Speciation analysis and bioaccessibility evaluation of trace elements in goji berries (Lycium Barbarum L.). J. Chromatogr. A 2017, 1492, 70-78. [CrossRef] [PubMed]

135. Jia, Y.Y.; Wang, L.; Ma, L.; Yang, Z.G. Speciation analysis of six arsenic species in marketed shellfish: Extraction optimization and health risk assessment. Food Chem. 2018, 244, 311-316. [CrossRef] [PubMed]

136. Reyes, L.H.; Mar, J.L.G.; Rahman, G.M.M.; Seybert, B. Simultaneous determination of arsenic and selenium species in fish tissues using microwave-assisted enzymatic extraction and ion chromatography-inductively coupled plasma mass spectrometry. Talanta 2009, 78, 983-990. [CrossRef] [PubMed]

137. Nan, K.; He, M.; Chen, B.B.; Chen, Y.J.; Hu, B. Arsenic speciation in tree moss by mass spectrometry based hyphenated techniques. Talanta 2018, 183, 48-54. [CrossRef] [PubMed]

138. Sentkowska, A.; Pyrzynska, K. Hydrophilic interaction liquid chromatography in the speciation analysis of selenium. J. Chromatogr. B 2018, 1074, 8-15. [CrossRef] [PubMed]

139. Le, X.C.; Li, X.F.; Lai, V.; Ma, M.; Yalcin, S.; Feldmann, J. Simultaneous speciation of selenium and arsenic using elevated temperature liquid chromatography separation with inductively coupled plasma mass spectrometry detection. Spectrochim. Acta B 1998, 53, 899-909. [CrossRef]

140. Ammann, A.A. Arsenic speciation by gradient anion exchange narrow bore ion chromatography and high resolution inductively coupled plasma mass spectrometry detection. J. Chromatogr. A 2010, 1217, 2111-2116. [CrossRef] [PubMed]

141. Milstein, L.S.; Essader, A.; Pellizzari, E.D.; Fernando, R.A.; Raymer, J.H.; Levine, K.E.; Akinbo, O. Development and application of a robust speciation method for determination of six arsenic compounds present in human urine. Environ. Health Perspect. 2003, 111, 293-296. [CrossRef] [PubMed]

142. Timerbaev, A.R. Element speciation analysis using capillary electrophoresis: Twenty years of development and applications. Chem. Rev. 2013, 113, 778-812. [CrossRef] [PubMed]

143. Liu, L.H.; He, B.; Yun, Z.J.; Sun, J.; Jiang, G.B. Speciation analysis of arsenic compounds by capillary electrophoresis on-line coupled with inductively coupled plasma mass spectrometry using a novel interface. J. Chromatogr. A 2013, 1304, 227-233. [CrossRef] [PubMed]

144. Li, J.H.; Liu, J.Y.; Lu, W.H.; Gao, F.F.; Wang, L.Y.; Ma, J.P.; Liu, H.T.; Liao, C.Y.; Chen, L.X. Speciation analysis of mercury by dispersive solid-phase extraction coupled with capillary electrophoresis. Electrophoresis 2018, 39, 1763-1770. [CrossRef] [PubMed]

145. Yang, F.F.; Li, J.H.; Lu, W.H.; Wen, Y.Y.; Cai, X.Q.; You, J.M.; Ma, J.P.; Ding, Y.J.; Chen, L.X. Speciation analysis of mercury in water samples by dispersive liquid-liquid microextraction coupled to capillary electrophoresis. Electrophoresis 2014, 35, 474-481. [CrossRef] [PubMed]

146. Li, P.J.; He, M.; Chen, B.B.; Hu, B. Automated dynamic hollow fiber liquid-liquid-liquid microextraction combined with capillary electrophoresis for speciation of mercury in biological and environmental samples. J. Chromatogr. A 2015, 1415, 48-56. [CrossRef] [PubMed]

147. Kovachev, N.; Aguirre, M.Á.; Hidalgo, M.; Simitchiev, K.; Stefanova, V.; Kmetov, V.; Canals, A. Elemental speciation by capillary electrophoresis with inductively coupled plasma spectrometry: A new approach by Flow Focusing ${ }^{\circledR}$ nebulization. Microchem. J. 2014, 117, 27-33. [CrossRef]

148. Liu, L.H.; Yun, Z.J.; He, B.; Jiang, G.B. Efficient interface for online coupling of capillary electrophoresis with inductively coupled plasma-mass spectrometry and its application in simultaneous speciation analysis of arsenic and selenium. Anal. Chem. 2014, 86, 8167-8175. [CrossRef] [PubMed]

149. Matusiewicz, H.; Ślachciński, M. Development of a new hybrid technique for inorganic arsenic speciation analysis by microchip capillary electrophoresis coupled with hydride generation microwave induced plasma spectrometry. Microchem. J. 2012, 102, 61-67. [CrossRef]

150. Timerbaev, A.R. Element speciation analysis by capillary electrophoresis: What are the hints on becoming a standard analytical methodology. Anal. Chim. Acta 2001, 433, 165-180. [CrossRef]

151. Clough, R.; Harrington, C.F.; Hill, S.J.; Madrid, Y.; Tyson, J.F. Atomic spectrometry update: Review of advances in elemental speciation. J. Anal. Atom. Spectrom. 2018, 33, 1103-1149. [CrossRef]

152. D’Ulivo, A.; Baiocchi, C.; Pitzalis, E.; Onor, M.; Zamboni, R. Chemical vapor generation for atomic spectrometry. A contribution to the comprehension of reaction mechanisms in the generation of volatile hydrides using borane complexes. Spectrochim. Acta B 2004, 59, 471-486. [CrossRef] 
153. Grijalba, A.C.; Fiorentini, E.F.; Martinez, L.D.; Wuilloud, R.G. A comparative evaluation of different ionic liquids for arsenic species separation and determination in wine varietals by liquid chromatography-hydride generation atomic fluorescence spectrometry. J. Chromatogr. A 2016, 1462, 44-54. [CrossRef] [PubMed]

154. Liu, C.X.; Xiao, Z.M.; Jia, Z.; Tian, J.; Liu, X.L.; Fan, X. Quantitative determination of arsenic species in feed using liquid chromatography-hydride generation atomic fluorescence spectrometry. Chin. J. Anal. Chem. 2018, 46, 537-542.

155. Wang, Y.; Li, Y.Q.; Lv, K.; Chen, X.L.; Yu, X.Y. A simple and sensitive non-chromatographic method for quantification of four arsenic species in rice by hydride generation-atomic fluorescence spectrometry. Spectrochim. Acta B 2018, 149, 197-202. [CrossRef]

156. Zhang, Y.L.; Miro, M.; Kolev, S.D. A novel on-line organic mercury digestion method combined with atomic fluorescence spectrometry for automatic mercury speciation. Talanta 2018, 189, 220-224. [CrossRef] [PubMed]

157. Grijalba, A.C.; Fiorentini, E.F.; Wuilloud, R.G. Ionic liquid-assisted separation and determination of selenium species in food and beverage samples by liquid chromatography coupled to hydride generation atomic fluorescence spectrometry. J. Chromatogr. A 2017, 1491, 117-125. [CrossRef] [PubMed]

158. dos Santos, G.S.; Silva, L.O.B.; Santos, A.F.; da Silva, E.G.P.; dos Santos, W.N.L. Analytical strategies for determination and environmental impact assessment of inorganic antimony species in natural waters using hydride generation atomic fluorescence spectrometry (HG-AFS). J. Braz. Chem. Soc. 2018, 29, 185-190. [CrossRef]

159. de Quadros, D.P.C.; Campanella, B.; Onor, M.; Bramanti, E.; Borges, D.L.G.; D’Ulivo, A. Mercury speciation by high-performance liquid chromatography atomic fluorescence spectrometry using an integrated microwave/UV interface. Optimization of a single step procedure for the simultaneous photo-oxidation of mercury species and photo-generation of $\mathrm{Hg}^{0}$. Spectrochim. Acta B 2014, 101, 312-319.

160. Ai, X.; Wang, Y.; Hou, X.D.; Yang, L.; Zheng, C.B.; Wu, L. Advanced oxidation using $\mathrm{Fe}_{3} \mathrm{O}_{4}$ magnetic nanoparticles and its application in mercury speciation analysis by high performance liquid chromatography-cold vapor generation atomic fluorescence spectrometry. Analyst 2013, 138, 3494-3501. [CrossRef] [PubMed]

161. Sun, Y.C.; Chen, Y.J.; Tsai, Y.N. Determination of urinary arsenic species using an on-line nano- $\mathrm{TiO}_{2}$ photooxidation device coupled with microbore LC and hydride generation-ICP-MS system. Microchem. J. 2007, 86, 140-145. [CrossRef]

162. Yu, X.P.; Deng, T.L.; Guo, Y.F.; Wang, Q. Arsenic species analysis in freshwater using liquid chromatography combined to hydride generation atomic fluorescence spectrometry. J. Anal. Chem. 2014, 69, 83-88. [CrossRef]

163. Musil, S.; Matoušek, T. On-line pre-reduction of pentavalent arsenicals by thioglycolic acid for speciation analysis by selective hydride generation-cryotrapping-atomic absorption spectrometry. Spectrochim. Acta B 2008, 63, 685-691. [CrossRef] [PubMed]

164. Caylak, O.; Elci, S.G.; Hol, A.; Akdogan, A.; Divrikli, U.; Elci, L. Use of an aminated Amberlite XAD-4 column coupled to flow injection cold vapour generation atomic absorption spectrometry for mercury speciation in water and fish tissue samples. Food Chem. 2019, 274, 487-493. [CrossRef] [PubMed]

165. Wang, X.J.; Chen, P.; Cao, L.; Xu, G.L.; Yang, S.Y.; Fang, Y.; Wang, G.Z.; Hong, X.C. Selenium speciation in rice samples by magnetic ionic liquid-based up-and-down-shaker-assisted dispersive liquid-liquid microextraction coupled to graphite furnace atomic absorption spectrometry. Food Anal. Method 2017, 10, 1653-1660. [CrossRef]

166. dos Santos, Q.O.; Silva, M.M.; Lemos, V.A.; Ferreira, S.L.C.; de Andrade, J.B. An online preconcentration system for speciation analysis of arsenic in seawater by hydride generation flame atomic absorption spectrometry. Microchem. J. 2018, 143, 175-180. [CrossRef]

167. Maratta, A.; Carrizo, B.; Bazan, V.L.; Villafane, G.; Martinez, L.D.; Pacheco, P. Antimony speciation analysis by hydride trapping on hybrid nanoparticles packed in a needle trap device with electro-thermal atomic absorption spectrometry determination. J. Anal. Atom. Spectrom. 2018, 33, 2195-2202. [CrossRef]

168. Welna, M.; Pohl, P.; Szymczycha-Madeja, A. Non-chromatographic speciation of inorganic arsenic in rice by hydride generation inductively coupled plasma optical emission spectrometry. Food Anal. Method 2019, 12, 581-594. [CrossRef]

169. Mo, J.M.; Li, Q.; Guo, X.H.; Zhang, G.X.; Wang, Z. Flow injection photochemical vapor generation coupled with miniaturized solution-cathode glow discharge atomic emission spectrometry for determination and speciation analysis of mercury. Anal. Chem. 2017, 89, 10353-10360. [CrossRef] [PubMed] 
170. Dundar, M.S.; Kaptan, F.; Caner, C.; Altundag, H. Speciation of antimony using dithizone ligand via cloud point extraction and determination by USN-ICP-OES. Atom. Spectrosc. 2018, 39, 100-105.

171. Marcinkowska, M.; Baralkiewicz, D. Multielemental speciation analysis by advanced hyphenated technique-HPLC/ICP-MS: A review. Talanta 2016, 161, 177-204. [CrossRef] [PubMed]

172. Popp, M.; Hann, S.; Koellensperger, G. Environmental application of elemental speciation analysis based on liquid or gas chromatography hyphenated to inductively coupled plasma mass spectrometry-A review. Anal. Chim. Acta 2010, 668, 114-129. [CrossRef] [PubMed]

173. Terol, A.; Marcinkowska, M.; Ardini, F.; Grotti, M. Fast determination of toxic arsenic species in food samples using narrow-bore high-performance liquid-chromatography inductively coupled plasma mass spectrometry. Anal. Sci. 2016, 32, 911-915. [CrossRef] [PubMed]

174. Cheng, H.Y.; Zhang, W.W.; Wang, Y.C.; Liu, J.H. Interfacing nanoliter liquid chromatography and inductively coupled plasma mass spectrometry with an in-column high-pressure nebulizer for mercury speciation. J. Chromaatogr. A 2018, 1575, 59-65. [CrossRef] [PubMed]

175. Bolea-Fernandez, E.; Balcaen, L.; Resano, M.; Vanhaecke, F. Interference-free determination of ultra-trace concentrations of arsenic and selenium using methyl fluoride as a reaction gas in ICP-MS/MS. Anal. Bioanal. Chem. 2015, 407, 919-929. [CrossRef] [PubMed]

176. Stiboller, M.; Raber, G.; Gjengedal, E.L.F.; Eggesbo, M.; Francesconi, K.A. Quantifying inorganic arsenic and other water-soluble arsenic species in human milk by HPLC/ICPMS. Anal. Chem. 2017, 89, 6266-6272. [CrossRef] [PubMed]

177. Izabela, K.; Adam, S.; Danuta, B. Total arsenic and arsenic species determination in freshwater fish by ICP-DRC-MS and HPLC/ICP-DRC-MS techniques. Molecules 2019, 24, 607. [CrossRef]

178. Marcinkowska, M.; Komorowicz, I.; Baralkiewicz, D. Study on multielemental speciation analysis of $\mathrm{Cr}(\mathrm{VI})$, $\mathrm{As}(\mathrm{III})$ and $\mathrm{As}(\mathrm{V})$ in water by advanced hyphenated technique HPLC/ICP-DRC-MS. Fast and reliable procedures. Talanta 2015, 144, 233-240. [CrossRef] [PubMed]

179. Bolea-Fernandez, E.; Balcaen, L.; Resano, M.; Vanhaecke, F. Overcoming spectral overlap via inductively coupled plasma-tandem mass spectrometry (ICPMS/MS). A tutorial review. J. Anal. Atom. Spectrom. 2017, 32, 1660-1679. [CrossRef]

180. Balcaen, L.; Bolea-Fernandez, E.; Resano, M.; Vanhaecke, F. Inductively coupled plasma-tandem mass spectrometry (ICP-MS/MS): A powerful and universal tool for the interference-free determination of (ultra) trace elements-A tutorial review. Anal. Chim. Acta 2015, 894, 7-19. [CrossRef] [PubMed]

181. Rodriguez-Gonzalez, P.; Alonso, J.I.G. Recent advances in isotope dilution analysis for elemental speciation. J. Anal. Atom. Spectrom. 2010, 25, 239-259. [CrossRef]

182. Jeong, J.S.; Lee, J.; Park, Y.N. Quantitative speciation of selenium in human blood serum and urine with AE-RP- and AF-HPLC-ICP/MS. Bull. Korean Chem. Soc. 2013, 34, 3817-3824. [CrossRef]

183. Castillo, A.; Boix, C.; Fabregat, N.; Roig-Navarro, A.F.; Rodriguez-Castrillon, J.A. Rapid screening of arsenic species in urine from exposed human by inductively coupled plasma mass spectrometry with germanium as internal standard. J. Anal. Atom. Spectrom. 2012, 27, 354-358. [CrossRef]

184. Petursdottir, A.H.; Gunnlaugsdottir, H. Selective and fast screening method for inorganic arsenic in seaweed using hydride generation inductively coupled plasma mass spectrometry (HG-ICP-MS). Microchem. J. 2019, 144, 45-50. [CrossRef]

185. Matousek, T.; Wang, Z.F.; Douillet, C.; Musil, S.; Styblo, M. Direct speciation analysis of arsenic in whole blood and blood plasma at low exposure levels by hydride generation-cryotrapping-inductively coupled plasma mass spectrometry. Anal. Chem. 2017, 89, 9633-9637. [CrossRef] [PubMed]

186. Tsai, Y.N.; Lin, C.H.; Hsu, I.H.; Sun, Y.C. Sequential photocatalyst-assisted digestion and vapor generation device coupled with anion exchange chromatography and inductively coupled plasma mass spectrometry for speciation analysis of selenium species in biological samples. Anal. Chim. Acta 2014, 806, 165-171. [CrossRef] [PubMed]

(c) 2019 by the authors. Licensee MDPI, Basel, Switzerland. This article is an open access article distributed under the terms and conditions of the Creative Commons Attribution (CC BY) license (http:/ / creativecommons.org/licenses/by/4.0/). 